1

\title{
AN EMPIRICAL EXAMINATION OF \\ INFORMATION BARRIERS TO \\ TRADE IN INSURANCE
}

\author{
John Cawley
}

Tomas Philipson

NBER Working Paper 5669

\section{NATIONAL BUREAU OF ECONOMIC RESEARCH 1050 Massachusetts Avenue \\ Cambridge, MA 02138 \\ July 1996}

For their valuable comments, we thank Gary Becker, Michael Boozer, Pierre-Andre Chiappori, Jim Heckman, Joe Hotz, Magnus Johannesson, Brigitte Madrian, Casey Mulligan, Charles Mullin, Derek Neal, and seminar participants at Brown University, University of Chicago, Delta, Lund University, The Midwestern Economics Meetings, Stockholm School of Economics, and RAND-UCLA. Both authors gratefully acknowledge financial support from NIA and thank LIMRA for providing data. This paper is part of NBER's research program in Health Care. Any opinions expressed are those of the authors and not those of the National Bureau of Economic Research.

(C) 1996 by John Cawley and Tomas Philipson. All rights reserved. Short sections of text, not to exceed two paragraphs, may be quoted without explicit permission provided that full credit, including (C) notice, is given to the source. 


\title{
AN EMPIRICAL EXAMINATION OF \\ INFORMATION BARRIERS TO \\ TRADE IN INSURANCE
}

\begin{abstract}
This paper tests restrictions implied by the canonical theory of insurance under asymmetric information using ideal data that contains the self-perceived and actual mortality risk of individuals, as well as the price and quantity of their life insurance.

We report several findings which are hard to reconcile with the canonical theory. First, we find a striking independence of self-perceived risk and the price of insurance. Second, we find strong evidence of the opposite type of non-linear pricing than predicted by theory: the theory predicts that prices rise with quantity, but we find that they fall. Third, we find that risk is negatively correlated with the quantity of insurance purchased although the theory predicts a positive correlation. Fourth, we find that a substantial fraction of individuals hold multiple insurance contracts, which casts doubt on the prediction that unit prices rise with quantity because multiple small contracts dominate a large one in such a case. Lastly, we test the accuracy of the self-perceived risk of the insured through estimating the induced profits they imply. We conclude by discussing the robustness of these results and the questions they raise for future theoretical models.
\end{abstract}

John Cawley

Department of Economics

University of Chicago

1126 East 59th Street

Chicago, IL 60637
Tomas Philipson

Department of Economics

University of Chicago

1126 East 59th Street

Chicago, IL 60637

and NBER 


\section{Introduction}

Economists have long studied the market distortions that result from the asymmetry of information between well-informed demanders and poorlyinformed suppliers of insurance. Government regulation and sponsorship of insurance is often justified with the claim that such asymmetric information results in adverse selection and underprovision of insurance. Indeed, this claim is taken as obvious by economists and is often used to rationalize almost a third of the U.S. federal budget through social insurance, such as Social Security and Medicare, and to explain the scarcity of markets in certain types of insurance (e.g., that for long term care or disability). ${ }^{2}$ Despite this well-known case for government intervention, there exists little systematic and quantitative evidence on the degree to which asymmetric information limits or affects trade in insurance. This paper evaluates the validity of these claims in the U.S. life insurance market, which, in spite of these claims, is a privately operated market and one of the most commonly held and largest forms of insurance in the U.S. and other countries. For example, in 1992 $78 \%$ of U.S. households reported owning life insurance, for a total of $\$ 11,105$ billion in awards. Indeed, life insurance is the most widely-held financial product in the U. S., including bank savings accounts. ${ }^{3}$ The life insurance market is particularly useful to analyze because the private information crucial in that market-with regard to health and mortality-is also crucial to government-sponsored health insurance and annuities, which make up the bulk of government insurance in many countries.

This paper tests the implication of canonical theory that private insurance markets characterized by asymmetric information provide inefficient levels of coverage. An important feature of this study is that we use direct evidence on the self-perceived and actual mortality risk of demanders of life insurance as well as the prices and quantities of their insurance. These data allow us to test not only the restrictions on price and quantity of traded insurance but also the restrictions on price, quantity, and the risk of the insured. Our main conclusion is that using these ideal data, several of our findings seem irreconcilable with canonical theory.

The paper may be outlined as follows. Section 2 outlines the restric-

\footnotetext{
${ }^{2}$ For example, see Stiglitz (1988) pp. 332-333 and Akerlof (1970) pp. 12-14.

${ }^{3}$ American Council of Life Insurance, Life Insurance Fact Book (p. 6.) and SMR Research Corporation, (1995), The New American Life Insurance Consumer.
} 
tions of competitive equilibrium insurance under, alternatively, symmetric and asymmetric information. We focus on the predictions of Rothschild and Stiglitz (1976), the most common model referred to for the trade reductions induced by private insurance under asymmetric information. The first restriction we discuss concerns the correlation of insurance demand with unit price across the risk of the insured. Under symmetric information, controlling for the loss to be insured, the amount of insurance purchased is predicted to be invariant with the price charged across consumers of different risk; the higher willingness to pay for insurance of riskier individuals is offset by the higher price they face. On the other hand, under asymmetric information, quantities are predicted to be positively correlated with unit prices, the opposite of bulk discounts, because insurers are predicted to design contracts so that the high risk can purchase large quantities of insurance, but at a high unit price. The low risk, on the other hand, are quantity-constrained, in order to make their contract undesirable to the high risk, but are charged a lower unit price commensurate with their lower risk. Since the high risk face quantities at higher prices, the two covary positively, as opposed to not covarying under symmetric information.

The second restriction concerns how much insurance is purchased by people of different risk. Controlling for the loss to be insured, symmetric information implies no difference in quantity across risk, whereas asymmetric information implies that the risky buy larger contracts. This implication follows from the low risks imposed on the quantity constraints. The theory predicts that good risks get poorly treated, which seems at odds with actual markets in which bad risks are avoided by insurers.

The third restriction we test concerns the joint distribution of prices and risk (whether such risk is self-perceived or actual). In competitive markets, both symmetric and asymmetric information imply that prices perfectly reflect the risk of the insured. Under symmetric information this simply follows from risk being priced out, but under asymmetric information, it is the result of risk groups self-selecting into contracts which perfectly reveal their risk type, permitting the insurer to price out risk.

The fourth restriction is an implicit prohibition on the insured owning multiple insurance contracts. The theory predicts that unit prices rise with quantity because the risky are willing to pay a high unit price commensurate with their higher risk because in exchange they can buy larger contracts. However, when the risky can buy several of the smaller, cheap, contracts 
designed for the low risk, they would pay less than if they bought a bigger, more expensive contract with one insurer. For example, if a million-dollar contract costs 5 cents on the dollar, and a half-million-dollar contract costs 1 cent on the dollar, then buying two of the half-million-dollar contracts is cheaper than buying the one-million-dollar contract. An insurer can not identify the risk of the insured by the size of the contract with their firm only. If consumers can buy more than one insurance contract, therefore, it casts considerable doubt on the prediction that unit price rises with quantity.

The fifth and final restriction we test concerns the profits of insurers. Naturally, any theory predicts that these must be positive given actual risk. However, the theory of asymmetric information predicts that profits estimated using the self-perceived risk of the insured should also be positive.

Section 3 tests these restrictions using data from three sources: (1) a random sample of policies collected by LIMRA International, which is a consortium of life insurance providers, (2) the Health and Retirement Study (HRS), and (3) The Asset and Health Dynamics Among The Oldest Old (AHEAD). The last two data sources allow us to directly assess how risk, whether selfperceived risk by demanders or actual mortality risk, is distributed across traded contracts because HRS and AHEAD report the mortality beliefs of respondents and the actual mortality of respondents between waves. These data thus allow us to test directly the discussed restrictions imposed on the relationship between quantity, price, and risk (both self-perceived and actual).

To illustrate part of our findings, consider Figure 1 which depicts the prices of life insurance for the company serving many US professional economists: Teacher's Insurance and Annuity Association (TIAA). Unit price (the cents charged per dollar of coverage) is shown across policy size. The figure illustrates that, contrary to canonical theory, but consistent with our more systematic evidence, TIAA offers bulk discounts in its coverage; the cents per dollar of award falls with the size of the award.

Not surprisingly, TIAA charges higher premia to insure older or smoking individuals. ${ }^{4}$ However, the bulk discount is $10 \%$ for awards over a quarter of a million dollars and $25 \%$ for awards greater than one million dollars.

\footnotetext{
${ }^{4}$ The price differential creates an incentive for smokers to masquerade as nonsmokers in
} 
The incentive compatibility constraints in the canonical theory of insurance under asymmetric information require that unit price rise with the size of the award, not fall, as illustrated in the figure.

Our results are captured by this simple figure but show a striking robustness across the three data sets. In each, we find that insurance demand is negatively correlated with unit price, i.e., there are bulk discounts in life insurance, as opposed to the positive correlation predicted. It is important to control for the fact that richer individuals both insure more and live longer and hence have lower prices of life insurance. The two surveys HRS and AHEAD are especially useful in this regard because they represent the best available data source, containing joint observations on mortality risk, income, and wealth. This permits us to accurately control for income effects on unit price. We also find that bulk discounts are robust to the use of instruments which are correlated with mortality but not the loss to be insured.

In each data source we find a negative correlation between risk and the amount of insurance demanded as well as a striking independence of price and risk, both findings which are hard to reconcile with the theory. Furthermore, in HRS and AHEAD we find that a substantial fraction (roughly a quarter) of the insured hold multiple insurance contracts. This is perhaps the simplest but strongest evidence against the non-linear pricing predicted by the theory.

Finally, we evaluate the beliefs of the insured by computing the profits implied if demanders were correct in their mortality beliefs. We find that profits are close to zero when estimated using actual risks, but positive when priced according to the beliefs of the insured, suggesting that the insured underestimate the likelihood of their deaths.

Section 4 discusses the robustness of our conclusions. We discuss the implications of sampling only a subset of the insured population (which is the case for the ages represented in AHEAD and HRS), the effects of measurement error in the self-perceived risk variable, and the effects of loadings in prices.

Since our results are not easily explained with existing theory, we conclude by discussing the theoretical implications of our findings. We suggest that the superiority of buyer information is overstated in the standard theory

order to pay lower premia. The potential for such adverse selection is eliminated through urine and blood tests, which make nicotine consumption common knowledge. Furthermore, insurance companies reserve the right to limit awards if misreporting of customers becomes evident after the death of the insured. 
of adverse selection; while buyers may have better idiosyncratic information, sellers may have better systematic information from observing claims across many buyers. We argue that the information advantage of sellers, as opposed to buyers, seems to be more important, and that this has important implications for the incentives of the insured to learn about their risk.

Our paper relates to several important papers that empirically assess the extent and implications of trade under asymmetric information. See, e.g., Bond (1984), Genesove (1992), Dionne and Doherty (1994), Puelz and Snow (1994), Foster and Rozensweigh (1993), and Townsend (1996). The implications discussed and tested here differ from those in that we have data on what has previously been unobserved: the relationship between self-perceived and actual risk with the prices and quantities of insurance demanded. Our evidence on the private information of the insured and their realized risks allows us to more directly evaluate models of insurance under asymmetric information.

\section{Equilibrium Insurance Under Symmetric Ver- sus Asymmetric Information}

This section outlines the conventional theories of insurance under asymmetric information, especially that of Rothschild and Stiglitz (1976). We first describe the theory, and then in four subsections, detail the four restrictions imposed by this model that will be tested in the subsequent sections.

Let $Q$ denote the quantity of insurance demanded, and $q(Q)$ the unit price (cents per dollar of coverage); $q(Q) Q$ is the total insurance premium. Let $p$ be the risk of death for a life insurance applicant in the covered period, and let $L$ be the dollar amount to be insured. Let $W$ be the initial wealth of the buyer, where $W_{1}$ and $W_{0}$ signify wealth when the loss does or does not occur. ${ }^{5}$

$$
W_{1}=W+Q-L-q(Q) Q
$$

\footnotetext{
${ }^{5}$ Rothschild and Stiglitz (1976), the theory tested here, model the demand for life insurance using state-independent utility. That is, they model demand as if life insurance is purchased by the policy beneficiaries to protect against a loss of income that would result from the death of the insured. State dependent utility would apply if one assumed that life insurance is demanded by the insured for his own benefit, not the benefit of the policy beneficiaries.
} 


$$
W_{0}=W-q(Q) Q
$$

If $U(W)$ denotes the Von Neumann-Morgenstern utility function, the expected utility of buying $Q$ units of insurance is

$E U(Q)=p U\left(W_{1}\right)+(1-p) U\left(W_{0}\right)=p U(W+Q-L-q(Q) Q)+(1-p) U(W-q(Q) Q)$

The demand function of insurance is therefore determined by

$$
Q(p, q, L, W) \in \operatorname{Argmax} E U(Q)
$$

which satisfies the familiar condition that the marginal rate of substitution equals the relative price

$$
\frac{p U^{\prime}\left(W_{1}\right)}{(1-p) U^{\prime}\left(W_{0}\right)}=\frac{1-q^{\prime}}{q^{\prime}}
$$

As an illustrative example, assume there is no wealth effect, as when the utility function is $U(W)=-\exp (-\theta W)$, and that there is no effect of quantity on unit price, as when $q(Q)=q$. In this case, it is easily shown that insurance demand equals the potential loss less an amount proportional to the overpricing of the insurance:

$$
Q(p, q, L, W)=L-\frac{R}{\theta}
$$

where $R=\ln ([q /(1-q)] /[p /(1-p)])$. Because $R=0$ under fair pricing, $R$ may be interpreted as a measure of overpricing of insurance.

\subsection{Trade Restrictions Under Symmetric Information}

The ideal data we will consider allows us to jointly observe $(p, q, Q, W, L)$. Therefore, we first describe the restrictions imposed upon it. Equilibrium in competitive insurance markets with symmetric information is characterized by actuarially fair prices, due to the more general prediction of competitive prices reflecting average minimum costs. In this case, the unit price of insurance equals the risk of the insured: $q_{S}(Q)=p$ for a person of risk class $p$. Under such fair pricing, each person fully insures against the loss.

$$
Q\left(p, q_{S}, L, W\right)=L, \quad L \leq W
$$


This holds for all concave and state-independent utility functions, which imply a preference for smoothing wealth over states. If competition holds prices at a fair level, then this implies that across customers each purchases the same quantity of insurance, irrespective of unit price they are charged. The reduced-form demand function is completely inelastic with respect to the unit price of insurance and risk:

$$
\frac{d Q}{d q_{S}}=0 \quad \frac{d Q}{d p}=0
$$

This is true because risk and unit price are perfectly correlated; while those of higher risk have a higher marginal utility of insurance, this is exactly offset by higher prices. Naturally, within a risk class demand curves are downward sloping, but across risk classes equilibrium demand does not covary with the unit price charged.

\subsection{Trade Restrictions Under Asymmetric Information}

Canonical theories of insurance under asymmetric information do not imply that demand is invariant to unit price. Instead, they predict that those of low risk are quantity constrained in the presence of those of higher risk. This occurs because insurers market contracts to the lower risk customers that are undesirable to those with higher risk. In their choice of contract size, applicants reveal their riskiness, and insurers can charge them accordingly. ${ }^{6}$ This implies that the unit price function under asymmetric information, denoted $q_{A}(Q)$, increases with the quantity of insurance purchased $\frac{d q_{A}}{d Q} \geq 0$. The important consequence of this is that, in contrast to the case of symmetric information, quantity is positively correlated with the risk of the insured as well as with the unit price.

$$
\frac{d Q}{d q_{A}}>0 \quad \frac{d Q}{d p}>0
$$

Since the relationship between unit price and risk is just the compounded effect of the two, the unit price covaries with risk as well, since $d q_{A} / d p=$ $\left(d q_{A} / d Q\right)(d Q / d p) \geq 0$.

\footnotetext{
${ }^{6}$ For a detailed discussion of the incentive compatibility constraints imposed by screening models, see Riley (1979) and Mailath (1987).
} 
Although these results hold for a continuum of risk classes, it is more simply illustrated for the case of two risk classes, $\underline{p}$ and $\bar{p}$, in Figure 2. The symmetric information contracts are $(L, \bar{q} L)$ and $(L, \underline{q} L)$ at which there is full insurance at fair and constant unit prices $\underline{q}=\underline{p}$ and $\bar{q}=\bar{p}$. This implies the zero covariation across buyers between unit price and quantity. The asymmetric information contracts are $(L, \bar{q} L)$ and $(C, q C)$, where $C$ is the constrained quantity of the low risk class. Smaller contracts are sold at lower unit prices; the reduced-form demand function is upward sloping due to the positive covariance between price and quantity across customers.

Thus, in contrast with the symmetric information case, under asymmetric information, holding insurable loss $L$ constant, the quantity of insurance exchanged is correlated with the unit price as well as the risk of the insured: $\frac{d Q}{d q} \geq 0$ and $\frac{d Q}{d p} \geq 0$.

In equilibrium the marginal benefit of insurance must equal its marginal cost for all risk classes; this is possible if the pricing function $q_{A}(Q)$ assigns higher unit prices for larger insurance contracts (i.e., it is convex). If the cost function is concave, then there exist bulk discounts and the type of separating equilibrium described by Rothschild and Stiglitz cannot exist because the pricing schedule is not incentive compatible due to the incentives for the low risk to not buy their contract.

A crucial assumption of the separating equilibrium described above is that it is impossible to purchase multiple contracts. To illustrate using Figure 2, if multiple contracts are allowed, then high risks may demand a number $L / C$ of the $C$-sized contracts and reduce their total premia from $q(L) L$ to $q(C) L$. However, the purchase by the high risk of a contract priced for the low risk would make the contract unprofitable for the insurer and hence cannot be an equilibrium. While some insurance companies require may applicants to list any policies that they hold, this may be for other reasons than to cap insurance purchases, and the systematic impact of this practice is an open empirical question.

Note that competitive equilibria under symmetric and asymmetric information both imply perfect correlation between risk and unit price. To make this more precise, let the mean of unit prices conditional on risk be 
approximated by the linear Taylor expansion

$$
E[p \mid q]=\gamma_{0}+\gamma_{1} q
$$

Then both symmetric and asymmetric information models imply that the coefficients are restricted according to $\gamma_{0}=0$ and $\gamma_{1}=1$

\subsection{The Restriction of Profitable Insurance}

A competitive equilibrium restriction imposed by all theories of insurance is naturally that sellers earn non-negative profits. However, when consumers are as well informed as assumed in the theory of asymmetric information then if the self-perceived risk of the insured is accurate, then the profits induced by these beliefs must be non-negative as well. Evaluating the profits at the self-perceived risk one gets

$$
\pi \equiv \int Q(p)(q(p)-p /(1+r)) d F(p) \geq 0
$$

where $r$ is the yearly interest rate and $Q(p)$ and $q(p)$ are the quantity and unit price of risk class $p$ in equilibrium. Profits are larger the more the future is discounted because insurers receive the premia before paying any awards. If the fact that a given policy is traded is proof of its profitability with respect to actual risk, then this restriction can be used to test whether buyers of insurance have better information than sellers about their risk. Specifically, if the self-perceived risk induces the insured imply negative profits, then we can reject the hypothesis that the risk beliefs of the insured are accurate. Note that such tests for positive subjective profits may be performed on risk classes conditionally $E[\pi \mid p]$ or unconditionally $E[\pi]$. Rejecting non-negative profits conditionally amounts to rejecting the joint hypothesis of correct information of buyers and no cross-subsidies, and rejecting non-negative profits unconditionally amounts to rejecting correct information of buyers.

\section{Tests of Restrictions using Data on Self- Perceived and Actual Risk}

This section empirically investigates the discussed restrictions using data that allows us to jointly observe the self-perceived and actual risk of the insured and the quantities and prices of their insurance. 


\subsection{The Data Sources}

We use public release data from the first waves of the Health and Retirement Study (HRS) ${ }^{7}$, and the Asset and Health Dynamics Among the Oldest Old (AHEAD). ${ }^{8}$ Both studies examine health, retirement, and economic status, but the HRS sample is drawn from persons who are between 51 and 61 and the AHEAD sample from persons above $70{ }^{9}$ Both studies over-sampled AfricanAmericans, Hispanics, and residents of Florida, but we use sample weights to produce a nationally representative sample. There were 12,652 respondents from 7,702 households in HRS and 8,223 respondents from 6,052 households in AHEAD.

It is important to stress that our empirical analysis is concerned with an individual spot market in life insurance since that type of market is the domain of the theory. ${ }^{10}$ Specifically, we restrict our analysis to term life insurance, the annual premia of which are structured to cover annual outlays; term policies do not build cash value. ${ }^{11}$ In other words, the annual unit price of term life insurance equals the insurance company's estimate of the probability that the insured will die in the next year. ${ }^{12}$ We excluded those with group insurance policies since their premia reflect not only their own risk but also that of the rest of the group. A total of 2,230 respondents in HRS reported owning individual term life insurance and 1305 AHEAD respondents report paying premia for any term life insurance; the latter were not asked

\footnotetext{
${ }^{7}$ University of Michigan Survey Research Center, May, 1995.

${ }^{8}$ University of Michigan Survey Research Center, December 1994.

${ }^{9}$ In both studies, spouses of age-eligible respondents were interviewed. We drop observations on spouses who were not themselves age eligible.

${ }^{10}$ There are several types of life insurance contracts. The most common is called ordinary and totaled $\$ 111,600$ per U.S. household representing $58 \%$ of all life insurance. Ordinary life insurance comes in two varieties: whole life and term. Whole life covers the insured for life and represents $62 \%$ of ordinary policies. Term life coverage, the remaining $38 \%$ of ordinary policies, lasts for a specific period of time and payment occurs only if insured dies within that period. Individual term life policyholders pay the entire premium, as opposed to holders of group insurance, who may pay only a small fraction of the total premium, with the rest paid by an employer or union.

${ }^{11}$ We dropped from our sample those who are unsure whether their life insurance is whole life or term; however, we also estimated our models with that group included in our sample and the results are not significantly different.

${ }^{12}$ Renewable term policies increase premia with each year of renewal an decreasing term policies lower the award. Level term policies offer a constant premium for several years.
} 
whether their policies are individual or group. However, evidence suggests that they are mainly individual policies; group life insurance is generally offered through employment and the vast majority of the AHEAD sample is retired. Evidence from the non-age-eligible spouses in HRS for whom we know the type of policy and who resemble our AHEAD sample supports this hypothesis: of HRS respondents aged 70 or over who pay premia for some term insurance, $75 \%$ (of 35 observations) have individual policies.

Tables $1 \mathrm{~A}$ through $1 \mathrm{D}$ display summary statistics of variables used in this paper. Table $1 \mathrm{~A}$ reports the statistics for the entire age-eligible AHEAD and HRS samples ${ }^{13}$; Table 1B corresponds to the uninsured in both samples, Table $1 \mathrm{C}$ to term life insurance holders, and Table $1 \mathrm{D}$ to those holding multiple term life insurance policies.

Of particular importance is the self-perceived risk of the insured. AHEAD respondents were asked: "Using a number from 0 to 100 , what do you think are the chances that you will live to be at least $[90,95$, or 100 , depending on the age of the respondent]." HRS respondents were asked: "Using a number from 0 to 10 , where 0 equals absolutely no chance and 10 equals absolutely certain, what do you think are the chances that you will live to be 75 or more? And how about the chances that you will live to be 85 or more?" 14

In order to be compared to annual premia in the individual spot market we analyze, these beliefs about future mortality must be converted to beliefs about mortality in one year. The Appendix details how we derived selfperceived one-year mortality hazards, and the table reports the results for two hazard models that were used to convert future mortality beliefs into current ones. One is a constant hazard model and the other is a linear one, and since the latter allows for growth in mortality hazards, it will lead to lower current levels. However, for some of our results we only retain the assumption that the order of risk is preserved across time when using dummies for the ten reported risk levels.

The unit price of a policy $q(Q)$ was estimated by dividing the reported annual term insurance premium $(q(Q) Q)$ by the term insurance award. In

\footnotetext{
${ }^{13}$ We drop respondents that failed to report mortality beliefs.

${ }^{14}$ Hurd and McGarry (1995) and Hamermesh (1985) conclude that survival estimates similar to these behave like probabilities, are close to life table averages, and covary with health and socioeconomic variables in the same manner as do actual survivals.
} 
AHEAD, respondents were asked about the characteristics of their largest term policy only, and of all of their whole life policies combined. In HRS, they were asked to report the total award and premia of all of their term policies, the total award on all of their whole life insurance, and the premia on only the largest two whole life insurance policies.

We are not able to estimate actual risk for AHEAD because only one wave of that study is currently available. However, we were able to estimate actual risk for HRS. ${ }^{15}$ We computed actual mortality risk as the fitted value of a logit regression of experienced mortality between the two waves of HRS on demographic and health characteristics. ${ }^{16}$ Because there was sample attrition and since we do not know whether attrited members are still alive, we computed two measures of fitted risk: an upper bound on mortality for which attrited sample members were assumed to be dead, and a lower bound on mortality for which attrited sample members were assumed to be alive.

In HRS, the number of children is derived by adding the number of children reported living at home and the number reported to be living away from home. In AHEAD, respondents were asked the number of children they had ever had. For both surveys, respondents were asked how many living siblings and grandchildren they have.

Both HRS and AHEAD have extremely detailed measures of income and wealth. While HRS and AHEAD attempted to interview all spouses, it asked for financial information about both spouses from only one of the respondents in the household. In AHEAD, total family income represents the couple's combined income, before taxes, for the year 1992 or 1993, depending on the time of the interview. In HRS, total family income equals the total household income for 1991; this is the sum of earnings, unemployment and workers' compensation, pensions, annuities, SSI, welfare, capital income, disability income, and unspecified "other" income.

In AHEAD, the loss of income from the death of the insured was directly

\footnotetext{
${ }^{15}$ We thank David Weir and HRS for providing us with the preliminary HRS data on mortality.

${ }^{16}$ The regressors in the logit regression include: age, squared age, height, weight, the first principal component of three measures of cognitive awareness, and dummy variables for: female, black, white, married, diabetes, smokes now, ever smoked, drinks alcohol, cancer, lung disease, heart disease, stroke, psychiatric problems, arthritis, asthma, back problems, kidney ailments, ulcers, high cholesterol, broken bones after age 45 , high blood pressure, eyeglasses, and a hospital stay in the last year.
} 
measured and was defined to include the pre-tax wages of the insured in 1992/93 plus the net annual loss that death would cause in the top three regular income sources (e.g., pensions, Veterans Benefits, and annuities). Net loss can be determined because respondents were asked the current amount of the payments, and how much (if anything) their spouse would continue to receive from that source if they were to die. In HRS, the loss of income from death of the insured was estimated as the insured's annual income from veterans' benefits, pensions, annuities, SSI, wages and salaries, bonuses, overtime, tips and commissions, professional practice, second jobs, military reserves, unemployment compensation, workers compensation, and social security (including disability, survivors benefits, and retirement). Unlike AHEAD, HRS does not record how much income a spouse would continue to receive from these sources if the insured dies.

The wealth variable constitutes assets minus debts. Assets include

retirement accounts, savings accounts, checking accounts, stocks, mutual funds, CDs, bonds, Treasury bills, money market funds, annuities, other investments, accounts receivable, real estate, cars, boats, airplanes, businesses, jewelry, and unspecified "other" assets. Debts include mortgages, credit card balances, medical debt, loans from relatives, life insurance policy loans, and unspecified "other" debt.

The detailed financial measures in these surveys are important since the restrictions discussed are conditional on the level of loss $L$, wealth $W$, and other components of demand such as the number of living relatives (who can provide assistance to survivors and also may be recipients of future bequests). An accurate measure of the financial loss that would result from the death of the insured is particularly elusive, because altruistic family members may step in and partially offset the financial losses (e.g., wage and pension income) that stem from the death of the insured.

There are advantages unique to each data set. The HRS specifies whether term policies are individual or group, and asks all respondents their beliefs about living to two ages. The AHEAD better measures the financial loss that would result from the death of the respondent.

\subsection{Tests of the Price and Quantity Restrictions}

In this section, we examine the restrictions on the correlation of unit price and quantity of insurance. The first set of evidence comes from a data source 
that uniquely captures this relationship, the 1994 Buyer's Study by LIMRA International, which examined a random sample of the 28 thousand new policies issued in the US by 47 companies. ${ }^{17}$ This sample contains a limited set of the demographic characteristics of the buyers of the policies as well as features of those policies including award size and premia. Figures $3 \mathrm{~A}-\mathrm{B}$ below plot the unit price as a function of the award size broken down by age and annual income of buyer. The first figure plots the unit prices across award sizes for different ages and the second for different income classes.

Although, the data plotted in these figures is not conditioned on any other characteristics that may determine the unit price, they both display the pattern that the unit price falls with the size of the policy. Unit price falls by an average of $80.8 \%$ per $\$ 1000$ insured in Figure $3 \mathrm{~A}$ and by an average of $89.8 \%$ in Figure 3B.

Although this evidence is consistent with bulk discounts, the pattern might disappear after controlling more fully for potential factors that affect both unit price and the demand for insurance. Therefore, we go on to test for bulk discounts using the

individual-level data of AHEAD and HRS. Since the restrictions we discussed concerned the reduced-form demand function across different risk classes, we consider the basic reduced-form specification

$$
\ln Q=\beta_{0}+\beta_{q} q+\beta_{W} W+\beta_{L} L
$$

Our discussed restriction is conditional on all loss and wealth determinants of insurance demand. However, loss and wealth have components that are observable and unobservable to the survey, as in $L=\left(X_{L}, U_{L}\right)$ and $W=$ $\left(X_{W}, U_{W}\right)$ where $X$ 's correspond to observables and $U$ 's to unobservables. For example, components of observable loss include Social Security and pension payments and those of observable wealth include housing and financial assets. The basic coefficient of interest is $\beta_{q}$ which measures the degree to which, controlling for the loss and wealth of the individual, unit price is correlated with reduced form demand; it is predicted to be zero under symmetric

\footnotetext{
${ }^{17}$ For a complete description of the survey see The Buyers Study nited States A Market Study of New Insureds and the Ordinary Life Insurance Purchased, LIMRA International, Windsor, CT.
} 
information and positive when low-risk types are quantity constrained as predicted under asymmetric information. Naturally, the zero effect of price on demand does not hold within a given risk class when demand curves slope downward, but concerns the demand across risks.

Tables $2 \mathrm{~A}$ and $2 \mathrm{~B}$, columns 1 and 2 , report the coefficient estimates of successively larger sets of reduced form specifications, testing whether the unit price covaries with insurance demand, controlling for the loss and wealth of the insured. Unit price is a function of age, but it is important to include age as a regressor in addition to unit price because the quantity of insurance purchased falls with age, as there is less income lost from the death of the insured, and age is probably the most important observable, as opposed to unobservable, factor used by insurers to set unit price. Therefore, even if there was fair pricing, there could appear a negative relationship between quantity and unit price if one did not control for age effects on insurance demand.

The major result reported in the table is that the correlation of unit price and quantity is statistically significant ${ }^{18}$ and negative; in other words, Tables 2 suggest bulk discounts. This result is opposite to the predictions of models of insurance under symmetric or asymmetric information. As we increase the amount of controls for loss, wealth, age of spouse, and size of family, unit price still remains statistically significant and negative. ${ }^{19}$

If higher unobserved wealth leads to better health and larger insurance purchases, then the negative correlation between unit prices and quantities reported in columns 1 and 2 of the two tables may be spurious. However, little income and wealth are left unrecorded in HRS and AHEAD; detailed measurement of assets and income was one of the major objectives of these surveys. Therefore, we believe that the income streams unmeasured by these surveys are relatively small, in particular, smaller than any other available data with comparable mortality information.

Even so, we re-estimated the models of Table 2 using several instruments for unit price which we believe are correlated with mortality risk but not with

\footnotetext{
${ }^{18} \mathrm{All}$ tests in this paper use the $5 \%$ significance level.

${ }^{19}$ In results not included here, we interacted unit price with the age, gender, race, and wealth of the insured. The interactions proved statistically insignificant, and the unit price remained significant and negative.
} 
unobserved components of wealth and loss (the results appear in columns 3 and 4 of Tables 2). For the AHEAD sample we used several instruments: height, the age of each parent at death, age, and dummies that equal one if the respondent has diabetes, and has living parents. In AHEAD age is assumed to be uncorrelated with unobservable income because sample members are at least 70 years old and generally on annuitized income. For the HRS sample we used as instruments height and a dummy variable which equalled one if the respondent has diabetes. We could not use age as an instrument because the HRS sample is of working age; age could be correlated with unobserved income. We regressed unit price on the instruments, and fitted values of unit price were computed following a standard two-stage least squares method. Our instruments are not highly correlated with unit price; the R-squared is .04 in the HRS, and .08 in the AHEAD, samples.

Tables 2A and 2B, columns 3 and 4 , indicate that fitted unit price,

like unit price itself, has a statistically significant and negative correlation with the quantity of insurance. In HRS, but not AHEAD, this is robust to the inclusion of controls for the number of family members, wealth, family income, and loss. ${ }^{20}$ Overall, the results of the two tables seem to suggest bulk discounts in life insurance.

\subsection{Tests of the Risk and Quantity Restrictions}

Insurance under symmetric information, controlling for the wealth and loss of the insured, implies that risk should be uncorrelated with the demand for insurance. Under asymmetric information, however, risk and the quantity of insurance should be positively related. Table 3 examines these restrictions using actual and self-perceived risk from AHEAD and HRS. Table 3 contains specifications of the reduced-form relationship of the type

$$
\ln Q=\beta_{0}+\beta_{P} P+\beta_{W} W+\beta_{L} L
$$

where $P$ is either self-perceived or actual mortality risk.

\footnotetext{
${ }^{20}$ If the $\log$ of the total quantity of insurance held, that is, the sum of whole life and term coverage, is used as the dependent variable in these specifications, the coefficient on unit price is either significant and negative or statistically insignificant.
} 
We used two methods to construct the self-perceived risk variable. The first method is described in the Appendix as a method for estimating a oneyear hazard. The second method avoids the parametric issues involved in converting the future mortality belief into the one-year probability by using decile dummies $[0,0.1, \ldots, 1.0]$ for the beliefs reported in AHEAD and HRS. This method avoids the problems inherent in a conversion of future beliefs into current beliefs. Using these dummy variables, we investigate whether those with higher beliefs of death in the future, who by most methods would have a higher belief of death in a year, demand relatively more insurance controlling for loss and wealth. In Table 3, the dummies measure the effects relative to the omitted category of a certainty of death. As Table $3 \mathrm{~A}$ indicates, the results are similar whether one uses the linear hazard or the risk dummies. The correlation between risk and quantity of insurance is significant and negative for the HRS sample, and not statistically significant for the AHEAD sample. Both of these findings contradict the positive relationship predicted by insurance under asymmetric information.

Table 3B contains the analogous specification for the actual risk of the insured in HRS, as measured by their predicted probability of dying between the first and second wave of this survey. The columns (1) and (2) of the table contain the estimates for the upper bound on mortality treating as dead all those attriting from the survey between wave 1 and 2 . The columns (3) and (4) are the corresponding results when those attriting are treated as alive. Again, we find a negative reduced-form relationship between risk and quantity of insurance. However, in all columns, actual risk is not statistically significant. Again, our results do not support the canonical theory prediction of a positive and significant correlation between risk and quantity of insurance.

\subsection{Tests of the Risk and Average Price Restrictions}

The third set of restrictions we discussed and investigate here concerns the joint distribution of risk and unit price. Figures $4 \mathrm{~A}$ and $4 \mathrm{~B}$ display the joint frequency over self-perceived risk and unit price pairs $(p, q)$ for the HRS and AHEAD samples. The figure displays the whisker plots of self-perceived risk 
as a function of the percentiles of the unit price variable. ${ }^{21}$ Under asymmetric and symmetric information, a strong covariance was predicted between the two variables, but the distributions displayed by the whisker plots indicate a different relationship.

Indeed, as opposed to the theory's prediction, the self-perceived mortality beliefs of buyers seem almost uncorrelated with unit price. The regressions of self-perceived risk on unit price that correspond to the figure indicate that the correlation is statistically significant, but the R-squared is less than .02 for both samples and both measures of self-perceived risk (the constant and linear hazard models).

The same pattern is present in Figures 5A and 5B below, which compare the self-perceived mortality risk with actual mortality risk between the two waves in HRS. The first figure $5 \mathrm{~A}$ is for the larger actual mortality risk when those attriting are assumed dead, as opposed to the second figure $5 \mathrm{~B}$, which is when they are assumed alive.

Again, contrary to the theory, there appears to be no correlation between self-perceived and actual risk. The regressions of self-perceived on actual risk that correspond to these figures indicate that the correlation is statistically significant, but the R-squared is .03 or less for both measures of actual risk and both measures of self-perceived risk. This result suggests that the asymmetric information advantage of consumers is not present in these data. ${ }^{22}$

\subsection{Tests of the Single-Contract Restriction}

Perhaps the simplest but most convincing argument against the canonical theory is that it is incompatible with people holding multiple insurance contracts. If the high-risk can buy several of the small, cheap contracts designed

\footnotetext{
${ }^{21}$ The whisker plot depicts the median, 25 th and 75 th percentiles, and bounds made up of $3 / 2$ times these percentiles.

${ }^{22}$ Wilson (1977) and others have studied equilibrium cross-subsidies, in which low-risk individuals obtain the best possible contract by cross-subsidizing the risky. Cross subsidies by low-risk groups may be observed because they are willing to compensate high-risks to obtain higher coverage than when they are quantity constrained. Such cross-subsidy restrictions imply coefficients on risk and price less than unity.
} 
for the low-risk, there should be no demand at higher quantities. For example, under the price schedules predicted under asymmetric information, it would be cheaper to buy two half-million-dollar contracts than a one-milliondollar one. Figure 6 reports the number of term insurance contracts held by our HRS and AHEAD sample members.

The figure depicts the overall distribution on the extensive margin as well as the distribution for equally-sized high-, medium-, and low-risk sample members. The figure suggests that multiple contracting is clearly feasible; ${ }^{23}$ roughly a third of those who hold term insurance hold multiple contracts. Furthermore, multiple contracting seems independent of risk. The latter finding is important because it says that high risk individuals are not more likely to engage in multiple contracting. ${ }^{24}$

\subsection{Tests of The Profit Restriction}

This section tests the last restriction that the profits implied by the beliefs of the insured must be non-negative. The estimated per-capita profit for different contracts are reported in Tables 4 A-D for HRS and AHEAD. The first column contains the sample size and the second reports profits under the lower and upper bounds of $r=0 \%$ and $r=10 \%$ yearly interest. Because premia are received before claims are paid, the larger the interest rate, the higher the estimated profits of the insurer.

\footnotetext{
${ }^{23}$ Furthermore, the total quantity of insurance rises with number of contracts held.

${ }^{24}$ If unit prices fall with quantity then it is not clear why multiple contracts are held by such a large portion of the sample. One possibility is a quantity constraint that operates independently of price and risk. In our data there is no relationship between risk, whether self-perceived or actual and the number of contracts held. In both surveys, the average self-perceived risk is identical for those holding one versus multiple term contracts. Similarly, the average actual risk is same for both groups in HRS. A logit regression in which the dependent variable reflects whether a person holds one or many contracts, which is regressed on demographic characteristics as well as risk also indicates no relationship between risk and the number of contracts held.
} 
The risk beliefs of the insured imply positive profits when a linear hazard is used; we cannot reject the hypothesis that the beliefs are accurate. However, the profitability result is highly sensitive to the way in which mortality beliefs about the future are converted into mortality beliefs about the next year. For example, if we use a constant hazard, instead of linear hazard, model, insurers appear to lose over $\$ 1100$ per customer. The difference is attributable to the fact that fewer people are predicted to die in the next year with a linear hazard model than a constant hazard.

\section{Features Affecting the Robustness of Our Analysis}

This section discusses the robustness of our results to features of

survey design which affect the degree of measurement error and which observables are collected.

\subsection{Loadings on Insurance Prices}

The restrictions we tested were derived with the assumption that prices were actuarially fair-meaning that revenues equalled the awards. The competitive market prediction is that prices equal the average minimum costs of production, which corresponds to fair pricing whenever the non-award costs of producing the contracts, e.g., wages of employees or regulation, ${ }^{25}$ are small on a per-insured basis. To assess the fairness assumption directly we used our direct measures of risk for HRS to calculate average profits per customer. We found that zero profits could not be rejected at standard levels of significance.

However, even when such costs are not small on a per-insured basis, the loadings may not affect our results. For example, under the common assumption that loadings are constant across the insured, on a percentage or absolute basis, then the correlations between unit prices and the discussed risks are unaffected; loaded prices are simply linear transformations of unloaded ones. Furthermore, the results on the sorting of risk classes across

\footnotetext{
${ }^{25}$ Pauly and Finsinger (1986) document that the premia are virtually unregulated; regulation mainly concerns reserve requirements.
} 
quantities of insurance, whether self-perceived or actual risk, does not concern prices and hence is independent of any such loading on prices. However, the levels of the premia are affected by loadings and therefore our profit tests are sensitive to loadings. Specifically, loading raises our measure of the risk beliefs of insurers (unit price) and makes insurers seem more profitable; this increases the chance of Type II error in the profitability test.

One possible explanation of the bulk discounts is that loadings, such as medical exams in the case of life insurance, are spread across a contract, and have a lesser effect on unit price the larger the contract. The fixed costs in life insurance are referred to as the policy fee of the contract and for term insurance ranges between $\$ 50-100$ per policy in 1996. For example, consider the pricing of the TIAA contracts depicted in Figure 1. Suppose that its unit prices are made up of a fixed policy fee of size $F$, plus a fair component, as in $q(Q)=(F+p Q) / Q=F / Q+p$. Then the unit price is decreasing and converges to the true risk, $q(Q) \rightarrow p$, as awards increase. The TIAA bulk discounts of 10 and 25 percent, regardless of age, then reveal the levels and determinants of such fixed costs for TIAA. In particular, if for high enough quantities, fixed costs are negligible $(q(Q)=p)$, then if $Q_{0}$ denotes a midsize policy that does not enjoy any bulk discount then we must have that the relationship $\left(F / Q_{0}+p\right) / p=1 / d$, or equivalently $F=\left[(1-d) Q_{0} / d\right] p$, holds whenever large claims are discounted at $d \%$. This implies that the absolute level of fixed costs must be risk dependent, e.g., increasing in age, which seems unlikely. Second, inserting reasonable levels for TIAA such as a mortality hazard of one percent $(p=0.01)$, a mid range claim of $Q_{0}=150 \mathrm{~K}$, and a discount of $d=.75$ for claims for which fixed costs may be ignored, one gets the level of the fixed cost $F=[(.25) 150 / .75] p=50 p$. In other words, for each percentage increase in the mortality rate, the fixed cost goes up by 500 dollars. These fixed costs seem excessive, and also it is not clear why they increase with risk. Regardless of the reason for a bulk discount, its existence is strong evidence against the separating equilibrium described by Rothschild and Stiglitz.

\subsection{Conditioning by Suppliers and Econometricians}

Our data is conditional on a subset of the insured population. In particular, the two surveys we studied are limited to ages 51-61 for HRS and over 70 for AHEAD, although of course term insurance is sold for all ages. If a sampled 
population differs in unobservable respects from the non-sampled population there may be cross-subsidies. If the sample is conditional on a characteristic that is observable to insurers, which presumably age is, then competition makes cross-subsidies unlikely between the sampled and the non-sampled population. ${ }^{26}$ Hence, the fact that both HRS and AHEAD are conditional on a subset of possible ages does not discount our findings, if there is full competition to insure these age categories. Furthermore, although the full support of ages is not sampled, the full support of risks may be observed, as there is considerable variance of risk conditional on the ages sampled. Since both unit prices and risk, i.e., $q$ and $p$, are observed, there are no omitted variables with respect to risk. There may be omitted variables that are correlated with both the demand for insurance and wealth or loss, but there is no risk-related variable missing; we observe the risk itself.

Consider testing for the discussed restrictions when there are multiple observable groups. Let $X$ be a finite set of observable categories that determines the mortality risk of the insured. For example, if there are only two observable classes so that $X$ is a gender dummy, say $X=1$ for females and $X=0$ for males, then we interpret the restrictions discussed to be conditioned on observables, that is, to hold both within the male and within the female group of insured customers. Since the econometrician may only observe a subset of all the variables that are observable to the supplier, it is useful to analyze how this affects the results.

Figure 7 below illustrates the effects of the econometrician not observing all observables of the supplier who in turn, under asymmetric information, does not observe all that the buyer observes. The figure represents demand and price combinations conditional on a given pair of wealth and loss levels $(W, L)$. It concerns the simplest case when the econometrician can condition on a binary dummy variable $Z$ (e.g., gender), the seller can condition on a dummy $X$ (e.g., medical test), and the buyer on a dummy $U$ (e.g., a parental health condition). The risks are abbreviated $p_{x u}$ for $X=x$ and $U=u$, with the risk conditional on only an observable category $p_{x}$.

In the first scenario represented by the first column there is symmetric information between the supply and demand side, both know $X$ but neither

${ }^{26}$ The sample is clearly not self-selected since age cannot be chosen. 
knows $U$. In the second scenario represented by the second column there is asymmetric information between suppliers and demanders such that both know $X$ but only demanders know $U$. The first column specifies the predicted quantity and price pairs when neither the seller nor the buyer can condition on $U$. The second column specifies the traded quantities and prices when only the buyer observes $U$ where $Q(p)$ is the quantity demanded by risk $p$. The figure illustrates several important points on whether the discussed restrictions can be inferred when the econometrician does not condition on something that the sellers conditions on, that is, $X$ in the figure. Suppose the econometrician did not observe $X$ and wanted to test whether the symmetric information condition $d Q / d q=0$ held. Since this condition holds whether one conditions on $X$ or not, rejecting it unconditionally implies rejecting for some value of $X$ conditionally. In other words, if the econometrician rejects the null when omitting controls of the seller, he still rejects the null. Under asymmetric information $Q(p)$ and $p$ are monotonically related, which implies that whenever this monotonicity holds conditional on a value of $X$, it holds unconditionally because the underlying risk is ordered across states. In other words, the ranking of all the states from high to low risk coincides with the ranking of all of them from low to high quantity. This implies that conditional on an $X$ the relationship is monotonically increasing. However, if the econometrician could not control on $X$, the relationship would still be increasing. Therefore, the sign of the covariance between price and quantity is preserved when the econometrician does not control for all the controls of the seller. ${ }^{27}$

\footnotetext{
${ }^{27}$ More generally we have that, since controls in regressions correspond to different condition sets, if $M$ is a discrete set of characteristics of the demanders, let $\Phi_{E}, \Phi_{S}$, and $\Phi_{D}$ be partitions of $M$ representing information sets of the econometrician, the supplyside, respective the demand side, where $\Phi_{E}$ is coarser than $\Phi_{S}$, which in turn is coarser than $\Phi_{E}$, as in Figure 6. Given wealth and loss levels $(W, L)$, under symmetric information no covariation of $(Q, q)$ when conditioning on $\Phi_{S}$ implies no covariation when conditioning on $\Phi_{E}$. Under asymmetric information, a monotonic relationship between $Q$ and $p$ on $\Phi_{D}$ implies a monotonic relationship conditioning on $\Phi_{E}$.
} 


\subsection{Expectations Data and Measurement Errors}

An important issue that may be raised against any study using expectations data $^{28}$ is that the self-reported mortality beliefs involve measurement error. However, if individuals are unable to use their beliefs to accurately respond to a survey, it seems unlikely that they can utilize it to such a sophisticated extent that market breakdowns will occur because of adverse selection. The conventional approach of assessing the quality of expectations data is to see if it influences behavior, in this case, the quantity of insurance demanded. However, in the context of insurance, the supply side has to be taken into account. In particular, under fair pricing, expectations are uncorrelated with insurance demand, so determining whether the self-reported mortality beliefs are useful by looking at whether they affect insurance demand involves a joint hypothesis regarding data quality and market behavior. ${ }^{29}$

In assessing how conventional measurement errors affect the results, consider when the measured unit price $\tilde{q}$ and mortality belief $\tilde{p}$ are related to the true values, as in

$$
\begin{gathered}
\tilde{q}=q+\eta_{q} \\
\tilde{p}=p+\eta_{p},
\end{gathered}
$$

where $\eta_{q}$ and $\eta_{p}$ are independent and mean zero errors. ${ }^{30}$

First, such errors will bias the estimated effect of risk on insurance demand towards zero which suggests that if reported risk is measured with error, the effects we find must be underestimated (in absolute terms). Second, our test for fair pricing follows from

$$
E[\tilde{p} \mid \tilde{q}]=E\left[p+\eta_{p} \mid q=\tilde{q}-\eta_{q}\right]=p .
$$

\footnotetext{
${ }^{28}$ For previous work using qualitative expectations data, see e.g., Nerlove (1983), Carlson and Parkin (1975), and Jacobs and Jones (1980) on firm expectations, and for recent work using quantitative expectations data for households see, e.g., Dominitz and Manski (1995, 1996), Hurd and McGarry (1996), and Hamermesh (1985).

${ }^{29}$ Any test of an economic hypothesis is a test of the joint hypothesis involving the data production process and the economic hypothesis itself (see Philipson (1995)). The difference between attitudinal and behavioral measures is that the latter can in principle be externally validated. If no external validation takes place, the common case in empirical economics, then there seems to be no difference between the two.

${ }^{30}$ Since $\tilde{p}$ and $\tilde{q}$ are bounded, the variance cannot be equal across $p$ and $q$ unless it is zero.
} 
The conditional mean function, although not the conditional variance, is the same. Lastly, the effect on estimated profit levels is somewhat different. The observed profits under measurement errors are given by

$$
\tilde{\pi} \equiv \int(\tilde{q}-\tilde{p} /(1+r)) Q d F(\tilde{p}, \tilde{q}) .
$$

When measurement errors have zero means this yields

$$
\tilde{\pi}=\int(q-p /(1+r)) Q d F\left(p+\eta_{p}, q+\eta_{q}\right) .
$$

Therefore, a sufficient condition for profits observed with error to be positive is that $q \geq p$ holds almost surely, in which case $\tilde{\pi} \geq 0$ is implied. Measurement error increases the likelihood of Type II error, that is, to accept that the mortality information of the insured is superior when it is not.

\section{Conclusion}

Using data on not only quantities and prices of insurance, but also on the self-perceived and actual risk of persons demanding life insurance, we tested several restrictions implied by the theory of insurance under both symmetric and asymmetric information. We found evidence of bulk discounts in insurance; that is, unit prices fall at higher quantities of insurance. Furthermore, we found a negative correlation between self-perceived risk, actual risk, and the quantity of insurance. We also found a lack of covariation between self-perceived and actual risk with unit price. Most dramatically, we found substantial evidence of multiple contracting, which indicates that unit prices that rise with quantity seem unlikely to be present. The results of our profit tests of the accuracy of buyer beliefs are inconclusive and sensitive to the way in which we convert a belief of mortality over several years into a belief about mortality in one year.

Our findings suggest several theoretical directions that may develop to better understand the discussed patterns in the data. We believe that canonical models of insurance exaggerate the superiority of the buyer's information relative to that of sellers. The handsome wages commanded by actuaries proves that knowledge of systematic, as opposed to idiosyncratic, mortality 
information is highly valued by insurers. ${ }^{31}$ More importantly, the information acquisition of the two sides of the market may interact: if insurers acquire much information, this may provide a disincentive for information acquisition by the insurance applicants. Because insurers may require access to medical records, applicants have a disincentive to have medical conditions diagnosed; that might encourage the insurer to charge a higher premium. When information acquisition is endogenous, the information asymmetry may actually be to the advantage of the insurer due to economies of scale.

\footnotetext{
${ }^{31}$ The classic reference on how to use such systematic knowledge about customer characteristics to set premia is Shepherd and Webster (1957).
} 


\section{References}

[1] Akerlof, G. (1970), "The Market for Lemons: Quality Uncertainty and the Market Mechanism," Quarterly Journal of Economics, 89, 488-500.

[2] Bond, E. and K. Crocker, "Smoking, Skydiving, and Knitting: The Endogenous Categorization of Risks in Insurance Markets with Asymmetric Information," Journal of Political Economy, 99(1), 177-200.

[3] Carlson, J., and M., Parkin, (1975), "Inflation Expectations," Economica, 42, 123-38.

[4] Bond, E., (1982), "A Direct Test of the Lemons Model: The Market for Used Pickup Trucks," American Economic Review, 74, 836-40.

[5] Cox, Donald and Tullio Jappelli, (1993) "The Effect of Borrowing Constraints on Consumer Liabilities." Journal of Money, Credit, and Banking. 25(2), 197ff.

[6] Dionne, Georges and Neil A. Doherty. "Adverse Selection, Commitment, and Renegotiation: Extension to and Evidence from Insurance Markets." Journal of Political Economy. 102(2), April 1994: 209-35.

[7] Dominitz, J., and C., Manski, (1995), "Eliciting Students Expectations of The Returns to Schooling," forthcoming, Journal of Human Resources.

[8] Genesove, D., (1993), "Adverse Selection in the Wholesale Used Car Market," Journal of Political Economy, 101, 644-665.

[9] Goldstein, G. and M. Pauly, (1976) "Group Health Insurance as a Local Public Good," in Rosett, R. (ed.) The Role of Health Insurance in the Health Services Sector (New York: NBER).

[10] Hamermesh, D., (1985) "Expectations, Life Expectancy, and Economic Behavior," Quarterly Journal of Economics (May) 389-408. 
[11] Hurd, M., and K. McGarry, (1995), "Evaluation of the Subjective Probability Distributions of Survival in the Health and Retirement Study," Journal of Human Resources, 30(supplement), S 268-92.

[12] Jacobs, R., and R., Jones, (1980), "Price Expectations in The United States 1947-1975," American Economic Review, 70, 269-76.

[13] Mailath, G. (1987), 'Incentive Compatibility in Signalling Games with A Continuum of Types,' Econometrica, 1349-65.

[14] Martin, Robert E. and David J. Smyth, (1991) "Adverse Selection and Moral Hazard Effects in the Mortgage Market: An Empirical Analysis." Southern Economic Journal, 57(4), 1071ff.

[15] Nerlove, M., (1983), "Expectations, Plans, and Realizations in Theory and Practice," Econometrica, v 51, 1251-79.

[16] Pauly, M., (1986), "Regulation and Quality Competition in the US Insurance Industry," in Pauly, M. and J. Finsinger, (eds.) The Economics of Insurance Regulation (New York: St. Martin's Press).

[17] Phelps, C., (1992) Health Economics, (New York: Harper Collins).

[18] Puelz, Robert and Arthur Snow. "Evidence on Adverse Selection: Equilibrium Signaling and Cross-Subsidization in the Insurance Market." Journal of Political Economy. 102(2), April 1994: 236ff.

[19] Riley, J, (1979), 'Informational Equilibrium,' Econometrica, 33159.

[20] Shepherd, P., and A. Webster, (1957), Selection of Risks, Chicago: Society of Actuaries.

[21] Spence, M., (1978), "Product Differentiation and Performance in Insurance Markets," Journal of Public Economics, 10, 427-47.

[22] Rothschild, M., and J. Stiglitz, (1976), "Equilibrium in Competitive Insurance Markets: An Essay on the Economics of Imperfect Information," Quarterly Journal of Economics, 80, 629-49. 
[23] Stiglitz, J., (1988), Economics of the Public Sector, New York: W. W. Norton Co.

[24] Suzman, Willis and Manton, (1992), The Oldest Old, Oxford University Press.

[25] Townsend, R., (1988), "Information Constrained Insurance: The Revelation Principle Extended," Journal of Monetary Economics, $21,411-450$.

[26] Townsend, R., and R. Muller, (1995), "Cropping Groups in a SemiArid Village Economy," unpublished manuscript.

[27] Townsend, R., (1995), "Financial Systems in Northern Thai Villages," Quarterly Journal of Economics, November 1995, 10111046.

[28] Weir, D., and R. Willis, (1995), "Life Insurance and the Gender Bias of Poverty in Widowhood," paper presented at HRS-2 Early Results Workshop, University of Michigan.

[29] Wilson, C., (1977), "A Model of Insurance Markets under Incomplete Information," Journal of Economic Theory, 16, 167-207.

[30] Wims, Mary E. "Adverse Selection: Case Study of One Company's Experience." Employee Benefits Journal. 16(4), December 1991: 26ff. 


\section{A APPENDIX: Computation of One-Year Self- Perceived Mortality Risk}

In both HRS and AHEAD, respondents provided a subjective belief of survival $S(t)$ after $t$ years. We converted these into one-year probabilities according to the constant and linear hazard models:

$$
\begin{gathered}
S(t)=\exp (-h t) \Rightarrow h=-\ln S(t) / t \Rightarrow p_{C}=1-S(1)=1-\exp (-h) \\
S(t)=\exp \left(-h t^{2} / 2\right) \Rightarrow h=-2 \ln S(t) / t^{2} \Rightarrow p_{I}=1-S(1)=1-\exp (-h / 2) .
\end{gathered}
$$

In the first model, the hazard function is constant across ages $h(t)=h$, while in the second model the hazard increases linearly over time $h(t)=h * t$. Survival probabilities of unity $p=1$ (21\% in AHEAD and $7.2 \%$ in HRS) are problematic for our constant hazard rate model because a certainty of death after many years is converted into a certainty of death in the next year. Furthermore, $11.7 \%$ of our AHEAD and $23 \%$ of our HRS samples reported zero probability of death. 


\section{AHEAD Variables}

Buyer's Belief ( $p$ ) -- linear hazard model Buyer's Beliel $(p)$-. constant hazard model Buyer's Estimate of Multiyear Survival Unit Price of Term Insurance (q) Own Term Life Insurance (dummy) Number of Term Life Policies Held Term Life Insurance Annual Premium Term Life Insurance Award (Q) Own Whole Life Insurance (dummy) Number of Whole Life Policies Held Whole Life Insurance Annual Premium Whole Life Insurance Award Number of Grandchildren

Number of Siblings

Number of Children

Married (dummy)

Age of Spouse (if married)

Age

White (dummy)

Black (dummy)

Female (dummy)

Annual Family Income

Wealth $(W)$

Loss of Income from Death of Insured (L)

\section{HRS Variables}

Buyer's Belief ( $p$ ) -- linear hazard model

Buyer's Belief $(p)$-- constant hazard model

Buyer's Estimate of Multiyear Survival

Actual Risk (Lower Bound)

Actual Risk (Upper Bound)

Unit Price (q)

Own Term Lile Insurance (dummy)

Number of Term Lile Policies Held

Term Life Insurance Annual Premium

Term Life Insurance Award (Q)

Own Whole Life Insurance (dummy)

Number of Whole Life Policies Held

Whole Life Insurance Annual Premium

Whole Life Insurance Award

Number of Grandchildren

Number of Siblings

Number of Children

Married (dummy)

Age of Spouse (if married)

Age

White (dummy)

Black (dummy)

Female (dummy)

Annual Family Income

Wealth (W)

Loss of Income from Death of Insured (L)

$\begin{array}{rr}\mathbf{N} & \text { Mean } \\ 5434 & 0.013 \\ 5434 & 0.142 \\ 5434 & 41.472 \\ 786 & 0.072 \\ 5430 & 0.339 \\ 5421 & 0.467 \\ 849 & 0.350 \\ 1669 & 7.529 \\ 5430 & 0.264 \\ 5412 & 0.436 \\ 794 & 0.001 \\ 1280 & 20.018 \\ 5368 & 5.520 \\ 5424 & 2.051 \\ 5434 & 2.572 \\ 5434 & 0.503 \\ 2695 & 73.593 \\ 5434 & 76.548 \\ 5434 & 0.908 \\ 5434 & 0.079 \\ 5434 & 0.613 \\ 5434 & 24.057 \\ 5434 & 200.234 \\ 5434 & 4.747\end{array}$

$\underline{N}$

9014

9014

9014

8326

8326

2903

9014

8973

2775

3920

9014

8998

2080

2622

8790

8790

8790

9014

6162

9014

9014

9014

9014

8896

8896

9014

0.092

0.532

53.417

264.557
Standard

Deviation

0.015

0.155

34.445

0.067

0.473

0.783

0.906

17.299

0.441

0.904

0.002

50.989

5.765

1.998

2.102

0.500

6.730

4.935

0.290

0.270

0.487

28.951

398.861

12.684

Standard

Mean

Deviation

0.005

0.076

2.950

0.029

0.037

0.038

0.500

0.823

0.893

117.473

0.474

0.885

1.738

106.019

4.226

2.154

2.014

0.441

6.644

3.138

0.379

0.289

0.499

55.627

566.243

40.995
Minimum

Maximum

0.000

0.067

0.000

0.499

0.000

0.0004

0.000

0.000

100.000

0.420

1.000

7.000

0.012

0.100

24.000

0.000

0.000

300.000

1.000

7.000

0.000

0.015

0.000

0.000

0.000

0.000

38.000

70.000

0.000

0.000

0.000

0.000

$-106.000$

$-37.164$

0.048

650.000

50.000

15.000

20.000

1.000

98.000

90.000

1.000

1.000

1.000

700.000

14655.000

208.400

Minimum Maximum

\subsection{0}

0.000

0.000

0.000

0.001

0.000

0.000

0.000

0.001

0.150

0.000

0.000

0.000

0.300

0.000

0.000

0.000

0.000

23.000

51.000

0.000

0.000

0.000

0.000

.745 .000

0.000
0.035

0.389

10.000

0.632

0.503

0.480

1.000

15.000

14.400

2000.000

1.000

15.000

42.000

2000.000

56.000

19.000

19.000

1.000

85.000

61.000

1.000

1.000

1.000

1309.000

8734.700

1250.000 


\section{AHEAD Varlables}

Buyer's Belief $(p)$-- linear hazard model

Buyer's Belief ( $p$ ) -- constant hazard model

Buyer's Estimate of Multiyear Survival

Number of Grandchildren

Number of Siblings

Number of Children

Married (dummy)

Age of Spouse (if married)

Age

White (dummy)

Black (dummy)

Female (dummy)

Annual Family Income

Wealth (W)

Loss of Income from Death of Insured (L)
$\underline{\mathbf{N}}$

HRS Varlables

Buyer's Belief ( $p$ ) -- linear hazard model

Buyer's Belief $(p)$-- constant hazard model

Buyer's Estimate of Multiyear Survival

Actual Risk (Lower Bound)

Actual Risk (Upper Bound)

Number of Grandchildren

Number of Siblings

Number of Children

Married (dummy)

Age of Spouse (if married)

Age

White (dummy)

Black (dummy)

Female (dummy)

Annual Family Income

Wealth $(W)$

Loss of Income from Death of Insured (L)
2453

2453

2453

2414

2446

2453

2453

1049

2453

2453

2453

2453

2453

2453

2453

Standard

Mean Devlation

0.014

0.149

41.598

5.464

1.989

2.555

0.436

74.489

77.229

0.904

0.077

0.706

23.034

191.492

3.590

\section{$\underline{N}$}

3036

3036

3036

2753

2753

2962

2962

2962

3036

1771

3036

3036

3036

3036

2918

2918

3036
Mean

Standard

Deviation

0.003

0.051

6.253

0.017

0.039

4.059

1.470

3.333

0.657

56.728

55.942

0.752

0.103

0.655

41.211

246.135

13.812

0.006

0.087

3.136

0.035

0.048

4.814

2.356

2.208

0.475

7.075

3.144

0.432

0.304

0.475

46.548

597.102

22.172

0.017
0.162

35.450

6.105

2.038

2.235

0.496

7.022

5.137

0.294

0.266

0.456

29.089

333.150

9.465
MInImum

0.000

0.000

0.000

0.000

0.000

0.000

0.000

44.000

70.000

0.000

0.000

0.000

0.000

$-96.100$

$-37.164$
Maximum

0.067
0.499
100.000
50.000
15.000
20.000
1.000
93.000
90.000
1.000
1.000
1.000
500.000
5304.000
121.692

\section{Minimum Maximum}

$0.000 \quad 0.035$

$0.000 \quad 0.389$

$0.000 \quad 10.000$

$0.000 \quad 0.482$

$0.002 \quad 0.503$

$0.000 \quad 56.000$

$0.000 \quad 14.000$

$0.000 \quad 19.000$

$0.000 \quad 1.000$

$29.000 \quad 82.000$

$51.000 \quad 61.000$

$0.000 \quad 1.000$

$0.000 \quad 1.000$

$0.000 \quad 1.000$

$0.000 * 600.000$

$-463.000 \quad 8734.700$

$0.000 \quad 600.000$

Notes: All financial variables are reported in thousands. 


\section{AHEAD Varlables}

Buyer's Belief $(p)$-- linear hazard model

Buyer's Belief $(p)$-- constant hazard model

Buyer's Estimate of Multiyear Survival

Unit Price of Term Insurance (q)

Number of Term Life Policies Held

Term Life Insurance Annual Premium

Term Life Insurance Award (Q)

Number of Grandchildren

Number of Siblings

Number of Children

Married (dummy)

Age of Spouse (if married)

Age

White (dummy)

Black (dummy)

Female (dummy)

Annual Family Income

Wealth (W)

Loss of Income from Death of Insured (L).
$\underline{N}$

HRS Varlables

Buyer's Belief $(p)$-- linear hazard model

Buyer's Belief $(p)$-- constant hazard model

Buyer's Estimate of Multiyear Survival

Actual Risk (Lower Bound)

Actual Risk (Upper Bound)

Unit Price (q)

Number of Term Life Policies Held

Term Life Insurance Annual Premium

Term Life Insurance Award (Q)

Number of Grandchildren

Number of Siblings

Number of Children

Married (dummy)

Age of Spouse (if married)

Age

White (dummy)

Black (dummy)

Female (dummy)

Annual Family Income

Wealth $(W)$

Loss of Income from Death of Insured (L)
1868
1868
1868
786
1859
849
1669
1845
1865
1868
1868
956
1868
1868
1868
1868
1868
1868
1868
Standard

Devlation

0.013

0.140

40.787

0.072

1.383

0.350

7.529

5.808

2.141

2.670

0.522

73.145

76.092

0.882

0.106

0.554

22.482

162.219

5.366
MInimum

0.000
0.000
0.000
0.0004
1.000
0.012
0.100
0.000
0.000
0.000
0.000
43.000
70.000
0.000
0.000
0.000
0.000
-106.000
-5.004

0.150

33.951

0.067

0.740

0.906

17.299

5.687

1.951

2.096

0.500

6.457

4.768

0.323

0.307

0.497

22.388

274.735

14.400

Standard

N

4367

4367

4367

4040

4040

2585

4326

2775

3920

4259

4259

4259

4367

3149

4367

4367

4367

4367

4367

4367

4367
Deviation

Mean

0.002

0.039

6.550

0.013

0.028

0.022

1.324

0.533

61.801

3.242

1.358

3.156

0.755

54.802

55.800

0.856

0.089

0.454

60.016

249.625

32.049
0.004

0.070

2.853

0.027

0.031

0.039

0.697

0.893

117.473

3.961

2.080

1.955

0.430

6.506

3.149

0.351

0.284

0.498

60.246

525.762

49.087
Minlmum

0.000

0.000

0.000

0.000

0.001

0.000

1.000

0.001

0.150

0.000

0.000

0.000

0.000

23.000

0.000

0.000

0.000

0.000

.745 .000

0.000
51.000
MaxImum

0.067

0.499

100.000

0.420

7.000

24.000

300.000

48.000

11.000

16.000

1.000

92.000

89.000

1.000

1.000

1.000

212.000

5280.000

208.400

Notes: All financial variables are reported in thousands. 
Table 1D: Summary Statistics and Definitions of Variables

For Those With Multiple Term Life Insurance Policies

\section{AHEAD Varlables}

Buyer's Belief $(p)$-- linear hazard model

Buyer's Belief $(p)$-- constant hazard model

Buyer's Estimate of Multiyear Survival

Unit Price of Term Insurance (q)

Number of Term Life Policies Held

Term Life Insurance Annual Premium

Term Life Insurance Award (Q)

Number of Grandchildren

Number of Siblings

Number of Children

Married (dummy)

Age of Spouse (if married)

Age

White (dummy)

Black (dummy)

Female (dummy)

Annual Family Income

Wealth (W)

Loss of Income from Death of Insured (L)
$\underline{\mathbf{N}}$

\section{HRS Varlables}

Buyer's Belief $(p)$-- linear hazard model

Buyer's Belief (p) -- constant hazard model

Buyer's Estimate of Multiyear Survival

Actual Risk (Lower Bound)

Actual Risk (Upper Bound)

Unit Price (q)

Number of Term Life Policies Held

Term Life Insurance Annual Premium

Term Life Insurance Award (Q)

Number of Grandchildren

Number of Siblings

Number of Children

Married (dummy)

Age of Spouse (if married)

Age

White (dummy)

Black (dummy)

Female (dummy)

Annual Family Income

Wealth $(W)$

Loss of Income from Death of Insured (L)
519

519

519

265

519

285

464

512

518

519

519

270

519

519

519

519

519

519

519

Standard

Devlation

Mean

$\underline{\mathbf{N}}$

1033

1033

1033

964

964

783

1033

855

934

1005

1005

1005

1033

778

1033

1033

1033

1033

1033

1033

1033
0.013

0.144

39.837

0.079

2.371

0.398

9.145

6.168

2.234

2.658

0.541

72.698

76.075

0.881

0.110

0.505

21.909

151.474

4.874

$$
\begin{array}{r}
0.015 \\
0.151 \\
34.604 \\
0.075 \\
0.777 \\
0.795 \\
20.451 \\
5.889 \\
2.014 \\
2.163 \\
0.499 \\
6.521 \\
4.614 \\
0.324 \\
0.313 \\
0.500 \\
20.130 \\
222.937 \\
12.086
\end{array}
$$

Standard

Devlation

Mean

0.002

0.039

6.437

0.013

0.029

0.016

2.312

0.696

107.673

2.991

1.306

3.136

0.785

53.943

55.669

0.882

0.073

0.336

65.758

296.351

36.196
MInImum

Maximum

0.000
0.000
0.000
0.0004
2.000
0.012
0.100
0.000
0.000
0.000
0.000
47.000
70.000
0.000
0.000
0.000
0.000
-106.000
-5.004

0.067

0.499

100.000

0.360

7.000

12.000

300.000

48.000

11.000

15.000

1.000

88.000

89.000

1.000

1.000

1.000

200.000

3090.000

180.000
Minimum

0.004

0.066

2.824

0.026

0.035

0.029

0.818

1.028

161.800

3.587

1.960

1.837

0.411

6.281

3.131

0.322

0.260

0.472

48.879

560.098

32.996
0.000

0.000

0.000

0.000

0.003

0.000

2.000

0.001

0.150

0.000

0.000

0.000

0.000

30.000

51.000

0.000

0.000

0.000

0.000

$-612500$

0.000
Maximum

0.035

0.389

10.000

0.347

0.415

0.348

15.000

9.600

2000.000

24.000

11.000

14.000

1.000

80.000

61.000

1.000

1.000

1.000

425.600

5740.000

410.000

Notes: All financial variables are reported in thou'sands. 
Variable

Constant

Unit Price

$-15.519$

Fitted Unit Price

Loss in Income from Death of Insure

Age

Wealth

Annual Family Income

Number of Grandchildren

Number of Siblings

Number of Children

Married

Age of Spouse

R Squared

Number of Observations
(1)

6.577
9.51

$-15.57$

$-13.15$

0.010

9.96

0.006

3.79

$-0.063$

$-5.08$

(2)

(3)

(4)

$\begin{array}{rr}3.587 & 9.439 \\ 4.22 & 0.63\end{array}$

$-87.590 \quad-91.334$

$\begin{array}{ll}-8.30 & -5.79\end{array}$

$0.002 \quad 0.002$

$1.15 \quad 1.10$

$0.033 \quad-0.157$

$\begin{array}{ll}1.76 & -0.29\end{array}$

$-0.19$

$-0.00004$

$-0.48$

$-0.0002$

$-2.24$

$0.004 \quad 0.0003$

2.87

0.2

$-0.024$

0.113

3.58

$-0.018$

0.003

$-1.07$

0.15

0.0004

$-0.07$

0.02

$-2.12$

2.810

0.656

6.42

1.01

$-0.049$

$-0.018$

$-6.45$

$-1.74$

0.324

937

0.358

0.214

0.261

898

937

898

Note: Results represent the coefficients and T statistics from a regression of the log of the term award on price and applicant characteristics.

Data: Health and Retirement Study 
Table 2B: Equilibrium Demand and Unit Prices in AHEAD

Dependent Varlable: log(Term Insurance Award)

Variable

Constant

Unit Price

(1)

4.243

7.17

$-4.320$

$-8.15$

(2)

(3)

(4)

11.876
1.34
-3.646
-6.87

Fitted Unit Price

Loss in Income from Death of Insured

Age

Wealth

Annual Family Income

Number of Grandchildren

Number of Siblings

Number of Children

Married

Age of Spouse

$$
\begin{array}{r}
-0.035 \\
-4.52
\end{array}
$$

0.021

10.78

0.013

4.75

$-0.253$

$-1.10$

0.0001

1.36

0.005

2.12

$-0.013$

$-1.85$

$-14.720 \quad-5.456$

$-2.75$

$-0.81$

$\begin{array}{rr}0.017 & 0.012 \\ 6.01 & 4.25\end{array}$

-0.004
-0.22

$-0.029$

$-0.01$

0.0001

1.21

0.004

1.07

$-0.009$

$-0.49$

$-0.019$

$-1.1$

$-0.022$

$-1.18$

0.012

0.59

$-0.007$

$-0.17$

2.731

5.05

3.199

4.20

$-0.033$

$-0.04$

$-4.50$

$-3.71$

0.277

693
0.343

682
0.227

612
0.308

601 
Table 3A: Equilibrium Demand and Reported Risk

Dependent variable: log(Term Insurance Award)

Variable

(1)

Constant

$1<=$ Mortality Risk $<.2$

$.2<=$ Mortality Risk $<.3$

$.3<=$ Mortality Risk $<.4$

$4<=$ Mortality Risk $<.5$

5<-Mortality Risk<.6

$6<=$ Mortality Risk $<.7$

$7<=$ Mortality Risk $<.8$

$8<=$ Mortality Risk $<.9$

$.9<=$ Mortality Risk $<=1$

Age

Age Squared

Loss in Income from Death of Insured

Wealth

Annual Family Income

Number of Grandchildren

Number of Siblings

Number of Children

Married

Age of Spouse

A Squared

Number of Observations
(3)

AHEAD

(4)

AHEAD

(5)

(6)

$\underset{H R S}{\text { HRS }}$

HRS HRS HRS HAS

$\begin{array}{rr}4.899 & 16.386 \\ 7.92 & 1.79 \\ -4.117 & -2.558 \\ -1.66 & -1.07\end{array}$

$4.640 \quad 15.310$

6.608

6.21

1.65

8.46

7.164

7.442

6.114

$-31.083 \quad-22.524$

$-4.15 \quad-3.05$
$0.375 \quad 0.147$

$0.83 \quad 0.34$

$0.320 \quad 0.252$

$\begin{array}{ll}0.75 & 0.62\end{array}$

$0.705 \quad 0.421$

$1.46 \quad 0.91$

$0.262 \quad 0.296$

$0.533 \quad 0.63$

$0.305 \quad 0.287$

$\begin{array}{ll}0.73 & 0.72\end{array}$

$0.445 \quad 0.316$

0.96

0.72

$0.299 \quad 0.270$

$0.68 \quad 0.65$

$0.440 \quad 0.390$

$\begin{array}{ll}1.00 & 0.93\end{array}$

$0.279 \quad 0.260$

$0.67 \quad 0.65$

$-0.048$

$-5.81$

$-0.367$

$-1.55$

$-0.049$

$-6.03$

$-0.346$

$-1.45$

0.002

1.42

0.023

11.04

0.012

4.41

0.023

0.002

1.32

0.012

4.33

0.0002

1.48

0.006

2.75

$-0.022$

$-2.88$

$-0.019$

$-1.13$

0.026

1.21

2.504

4.49

$-0.030$

$-3.90$

10.93

0.0002

1.52

0.006

2.67

$-0.021$

$-2.71$

$-0.019$

$-1.05$

0.022

1.00

2.550

4.48

$-0.030$

$-3.90$

$\begin{array}{rr}0.211 & 0.298 \\ 693 & 682\end{array}$

$-0.070$

$-5.02$

0.011

10.28

-0.00002
-0.16

0.004

2.87

$-0.046$

$-3.20$

$-0.023$

$-1.26$

0.011

0.38

3.199

6.75

$-0.055$

$-6.62$

$-0.183$

$-1.07$

$-0.073$

$-0.202-0.134$

$\begin{array}{ll}-1.10 & -0.75\end{array}$

$-0.081 \quad 0.050$

$\begin{array}{ll}-0.36 & 0.23\end{array}$

$-0.414 \quad-0.283$

$-2.63 \quad-1.82$

$-0.400 \quad-0.070$

$\begin{array}{ll}-1.57 & -0.27\end{array}$

$-0.274 \quad-0.127$

$-1.08 \quad-0.51$

$-0.388 \quad-0.255$

$-1.66-1.13$

$-0.999 \quad-0.866$

$-3.45 \quad-3.17$

$-0.864 \quad-0.609$

$-0.081 \quad-0.095$
-5.91

$-5.91 \quad-0.18$

0.0006

0.13

$0.011 \quad 0.006$

$10.09 \quad 3.96$

$-0.00002$

$-0.21$

$-0.004$

2.77

$-0.047$

$-3.25$

$-0.026$

$-1.39$

0.016

0.53

3.226

6.82

$-0.055$

$-6.69$

0.164
937

0.241

898 $\begin{array}{ll}-4.32 & -3.06\end{array}$

Note: Results represent the coefficients and T statistics from a regression of the log of the term award on reported risk.

In HRS, multiyear survivals were reported as integers between 0 and 10 .

In AHEAD, multiyear survivals were reported as integers between 0 and 100 .

The omitted calegory is a reported mortality risk between 0 and 1.1 .

The method of estimating one-year hazards from the reported mortality estimates

is described in Appendix 1.

Data: Health and Retirement Study, Asset and Health Dynamics Among the Oldest Old 
Table 3B: Equilibrium Demand and Empirical Risk in HRS

Dependent varlable: log(Term Insurance Award)

\begin{tabular}{|c|c|c|c|c|}
\hline Variable & $\frac{(1)}{\text { HRS }}$ & $\frac{(2)}{H R S}$ & $\frac{(3)}{H R S}$ & $\frac{(4)}{H R S}$ \\
\hline Constant & $\begin{array}{r}7.147 \\
8.85\end{array}$ & $\begin{array}{r}12.690 \\
0.80\end{array}$ & $\begin{array}{r}0.396 \\
0.80\end{array}$ & $\begin{array}{r}9.680 \\
0.61\end{array}$ \\
\hline Actual Risk (Upper Bound) & $\begin{array}{r}0.615 \\
0.60\end{array}$ & $\begin{array}{r}1.620 \\
1.51\end{array}$ & & \\
\hline Actual Risk (Lower Bound) & & & $\begin{array}{r}0.396 \\
0.26\end{array}$ & $\begin{array}{r}0.727 \\
0.48\end{array}$ \\
\hline Loss in Income from Death of Insured & $\begin{array}{l}0.011 \\
10.06\end{array}$ & $\begin{array}{r}0.006 \\
3.80\end{array}$ & $\begin{array}{l}0.011 \\
10.05\end{array}$ & $\begin{array}{r}0.006 \\
3.81\end{array}$ \\
\hline Age & $\begin{array}{r}-0.082 \\
-5.68\end{array}$ & $\begin{array}{r}-0.338 \\
-0.59\end{array}$ & $\begin{array}{r}-0.082 \\
-5.59\end{array}$ & $\begin{array}{r}-0.229 \\
-0.40\end{array}$ \\
\hline Age Squared & & $\begin{array}{r}0.003 \\
0.55\end{array}$ & & $\begin{array}{r}0.002 \\
0.36\end{array}$ \\
\hline Wealth & & $\begin{array}{r}-0.00007 \\
-0.70\end{array}$ & & $\begin{array}{r}-0.0001 \\
-0.77\end{array}$ \\
\hline Annual Family Income & & $\begin{array}{r}0.004 \\
3.14\end{array}$ & & $\begin{array}{r}0.004 \\
3.13\end{array}$ \\
\hline Number of Grandchildren & & $\begin{array}{r}-0.041 \\
-2.66\end{array}$ & & $\begin{array}{r}-0.040 \\
-2.60\end{array}$ \\
\hline Number of Siblings & & $\begin{array}{r}-0.022 \\
-1.10\end{array}$ & & $\begin{array}{r}-0.023 \\
-1.14\end{array}$ \\
\hline Number of Children & & $\begin{array}{r}-0.010 \\
-0.33\end{array}$ & & $\begin{array}{r}-0.010 \\
-0.31\end{array}$ \\
\hline Married & & $\begin{array}{r}3.260 \\
6.54\end{array}$ & & $\begin{array}{r}3.250 \\
6.52\end{array}$ \\
\hline Age of Spouse & & $\begin{array}{r}-0.055 \\
-6.30\end{array}$ & & $\begin{array}{r}-0.056 \\
-6.40\end{array}$ \\
\hline $\begin{array}{l}\text { R Squared } \\
\text { Number of Observations }\end{array}$ & $\begin{array}{r}0.146 \\
857\end{array}$ & $\begin{array}{r}0.229 \\
822\end{array}$ & $\begin{array}{r}0.145 \\
857\end{array}$ & $\begin{array}{r}0.227 \\
822\end{array}$ \\
\hline
\end{tabular}

R Squared
Number of Observations

$\begin{array}{rr}146 & 0.229 \\ 857 & 822\end{array}$

857

822

Note: Results represent the coefficients and $T$ statistics from a regression of the log of the term award on empirical risk.

Empirical risk is the likelihood of death, estimated from a logit regression

of mortality on demographic characteristics. Empirical risk exists for HRS only. Attrited sample members are assumed to be dead in the upper bound of mortality and alive in the lower bound.

Data: Health and Retirement Study 
Table 4A: Profits Implied by the Mortality Beliefs of the Insured in HRS (Beliefs Constructed Using a Linear Hazard Model)

\begin{tabular}{|c|c|c|c|c|c|c|}
\hline Population & Variable: & $\underline{\mathbf{N}}$ & Mean & $\begin{array}{l}\text { Standard } \\
\text { Error }\end{array}$ & Minimum & Maximum \\
\hline Entire & Profit Under $0 \%$ Discounting & 937 & 0.427 & 0.025 & $\begin{array}{l}-1.382 \\
-1.188\end{array}$ & $\begin{array}{l}10.406 \\
10.442\end{array}$ \\
\hline Males & $\begin{array}{l}\text { Profit Under } 0 \% \text { Discounting } \\
\text { Profit Under } 10 \% \text { Discounting }\end{array}$ & $\begin{array}{l}451 \\
451\end{array}$ & $\begin{array}{l}0.561 \\
0.574\end{array}$ & $\begin{array}{l}0.045 \\
0.045\end{array}$ & $\begin{array}{l}-0.964 \\
-0.848\end{array}$ & $\begin{array}{l}10.406 \\
10.442\end{array}$ \\
\hline Females & $\begin{array}{l}\text { Profit Under } 0 \% \text { Discounting } \\
\text { Profit Under } 10 \% \text { Discounting }\end{array}$ & $\begin{array}{l}486 \\
486\end{array}$ & $\begin{array}{l}0.297 \\
0.301\end{array}$ & $\begin{array}{l}0.024 \\
0.024\end{array}$ & $\begin{array}{l}-1.382 \\
-1.188\end{array}$ & $\begin{array}{l}7.524 \\
7.525\end{array}$ \\
\hline Nonwhites & $\begin{array}{l}\text { Profit Under } 0 \% \text { Discounting } \\
\text { Profit Under } 10 \% \text { Discounting }\end{array}$ & $\begin{array}{l}262 \\
262\end{array}$ & $\begin{array}{l}0.365 \\
0.373\end{array}$ & $\begin{array}{l}0.034 \\
0.034\end{array}$ & $\begin{array}{l}-0.964 \\
-0.848\end{array}$ & $\begin{array}{l}6.532 \\
6.534\end{array}$ \\
\hline Whites & $\begin{array}{l}\text { Profit Under } 0 \% \text { Discounting } \\
\text { Profit Under } 10 \% \text { Discounting }\end{array}$ & $\begin{array}{l}675 \\
675\end{array}$ & $\begin{array}{l}0.440 \\
0.449\end{array}$ & $\begin{array}{l}0.031 \\
0.032\end{array}$ & $\begin{array}{l}-1.382 \\
-1.188\end{array}$ & $\begin{array}{l}10.406 \\
10.442\end{array}$ \\
\hline Nonblacks & $\begin{array}{l}\text { Prolit Under } 0 \% \text { Discounting } \\
\text { Profit Under } 10 \% \text { Discounting }\end{array}$ & $\begin{array}{l}760 \\
760\end{array}$ & $\begin{array}{l}0.433 \\
0.443\end{array}$ & $\begin{array}{l}0.029 \\
0.029\end{array}$ & $\begin{array}{l}-1.382 \\
-1.188\end{array}$ & $\begin{array}{l}10.406 \\
10.442\end{array}$ \\
\hline Blacks & $\begin{array}{l}\text { Profit Under } 0 \% \text { Discounting } \\
\text { Profit Under } 10 \% \text { Discounting }\end{array}$ & $\begin{array}{l}177 \\
177\end{array}$ & $\begin{array}{l}0.374 \\
0.379\end{array}$ & $\begin{array}{l}0.041 \\
0.041\end{array}$ & $\begin{array}{l}-0.398 \\
-0.316\end{array}$ & $\begin{array}{l}6.532 \\
6.534\end{array}$ \\
\hline
\end{tabular}

Notes: Profit under $0 \%$ discounting is equal to (unit price - buyer beliefs) *term award.

Profit under $10 \%$ discounting is equal to (unit price - buyer beliefs/1.1) term award.

Data: HRS.

Table 4B: Profits Implied by the Mortality Beliefs of the Insured in HRS (Beliefs Constructed Using a Constant Hazard Model)

\begin{tabular}{|c|c|c|c|c|c|c|}
\hline Population & Variable: & $\underline{\mathbf{N}}$ & Mean & $\begin{array}{l}\text { Standard } \\
\text { Error }\end{array}$ & Minimum & Maximum \\
\hline Entire & $\begin{array}{l}\text { Profit Under } 0 \% \text { Discounting } \\
\text { Profit Under } 10 \% \text { Discounting }\end{array}$ & $\begin{array}{l}937 \\
937\end{array}$ & $\begin{array}{l}-1.144 \\
-0.992\end{array}$ & $\begin{array}{l}0.122 \\
0.110\end{array}$ & $\begin{array}{l}-61.450 \\
-55.379\end{array}$ & $\begin{array}{l}7.258 \\
7.284\end{array}$ \\
\hline Males & $\begin{array}{l}\text { Profit Under } 0 \% \text { Discounting } \\
\text { Profit Under } 10 \% \text { Discounting }\end{array}$ & $\begin{array}{l}451 \\
451\end{array}$ & $\begin{array}{l}-1.798 \\
-1.571\end{array}$ & $\begin{array}{l}0.219 \\
0.198\end{array}$ & $\begin{array}{l}-61.450 \\
-55.379\end{array}$ & $\begin{array}{l}6.455 \\
6.596\end{array}$ \\
\hline Females & $\begin{array}{l}\text { Profit Under } 0 \% \text { Discounting } \\
\text { Profit Under } 10 \% \text { Discounting }\end{array}$ & $\begin{array}{l}486 \\
486\end{array}$ & $\begin{array}{l}-0.502 \\
-0.425\end{array}$ & $\begin{array}{l}0.106 \\
0.097\end{array}$ & $\begin{array}{l}-39.677 \\
-36.002\end{array}$ & $\begin{array}{l}7.258 \\
7.284\end{array}$ \\
\hline Nonwhites & $\begin{array}{l}\text { Profit Under } 0 \% \text { Discounting } \\
\text { Profit Under } 10 \% \text { Discounting }\end{array}$ & $\begin{array}{l}262 \\
262\end{array}$ & $\begin{array}{l}-0.897 \\
-0.775\end{array}$ & $\begin{array}{l}0.158 \\
0.144\end{array}$ & $\begin{array}{l}-16.516 \\
-14.986\end{array}$ & $\begin{array}{l}6.095 \\
6.137\end{array}$ \\
\hline Whites & $\begin{array}{l}\text { Profit Under } 0 \% \text { Discounting } \\
\text { Prolit Under } 10 \% \text { Discounting }\end{array}$ & $\begin{array}{l}675 \\
675\end{array}$ & $\begin{array}{l}-1.194 \\
-1.036\end{array}$ & $\begin{array}{l}0.151 \\
0.137\end{array}$ & $\begin{array}{l}-61.450 \\
-55.379\end{array}$ & $\begin{array}{l}7.258 \\
7.284\end{array}$ \\
\hline Nonblacks & $\begin{array}{l}\text { Profit Under } 0 \% \text { Discounting } \\
\text { Prolit Under } 10 \% \text { Discounting }\end{array}$ & $\begin{array}{l}760 \\
760\end{array}$ & $\begin{array}{l}-1.227 \\
-1.067\end{array}$ & $\begin{array}{l}0.141 \\
0.128\end{array}$ & $\begin{array}{l}-61.450 \\
-55.379\end{array}$ & $\begin{array}{l}7.258 \\
7.284\end{array}$ \\
\hline Blacks & $\begin{array}{l}\text { Profit Under } 0 \% \text { Discounting } \\
\text { Profit Under } 10 \% \text { Discounting }\end{array}$ & $\begin{array}{l}177 \\
177\end{array}$ & $\begin{array}{l}-0.434 \\
-0.356\end{array}$ & $\begin{array}{l}0.113 \\
0.104\end{array}$ & $\begin{array}{r}-10.562 \\
-9.556\end{array}$ & $\begin{array}{l}6.095 \\
6.137\end{array}$ \\
\hline
\end{tabular}

Noles: Profit under $0 \%$ discounting is equal to (unit price - buyer beliefs) ${ }^{*}$ term award. Profit under $10 \%$ discounting is equal to (unit price - buyer beliefs $/ 1.1$ ) ${ }^{*}$ term award.

Data: HRS 
Table 4C: Profits Implied by the Mortality Beliefs of the Insured in AHEAD (Beliefs Constructed Using a Linear Hazard Model)

\begin{tabular}{|c|c|c|c|c|c|c|}
\hline Population & Variable: & $\underline{\mathbf{N}}$ & Mean & $\begin{array}{l}\text { Standard } \\
\text { Error }\end{array}$ & Minimum & Maximum \\
\hline Entire & $\begin{array}{l}\text { Profit Under } 0 \% \text { Discounting } \\
\text { Profit Under } 10 \% \text { Discounting }\end{array}$ & $\begin{array}{l}693 \\
693\end{array}$ & $\begin{array}{l}0.267 \\
0.276\end{array}$ & $\begin{array}{l}0.036 \\
0.036\end{array}$ & $\begin{array}{l}-1.791 \\
-1.583\end{array}$ & $\begin{array}{l}23.382 \\
23.438\end{array}$ \\
\hline Males & $\begin{array}{l}\text { Profit Under } 0 \% \text { Discounting } \\
\text { Profit Under } 10 \% \text { Discounting }\end{array}$ & $\begin{array}{l}323 \\
323\end{array}$ & $\begin{array}{l}0.389 \\
0.400\end{array}$ & $\begin{array}{l}0.076 \\
0.076\end{array}$ & $\begin{array}{l}-0.792 \\
-0.656\end{array}$ & $\begin{array}{l}23.382 \\
23.438\end{array}$ \\
\hline Females & $\begin{array}{l}\text { Profit Under } 0 \% \text { Discounting } \\
\text { Profit Under } 10 \% \text { Discounting }\end{array}$ & $\begin{array}{l}370 \\
370\end{array}$ & $\begin{array}{l}0.164 \\
0.170\end{array}$ & $\begin{array}{l}0.013 \\
0.013\end{array}$ & $\begin{array}{l}-1.791 \\
-1.583\end{array}$ & $\begin{array}{l}2.145 \\
2.147\end{array}$ \\
\hline Nonwhites & $\begin{array}{l}\text { Profit Under } 0 \% \text { Discounting } \\
\text { Profit Under } 10 \% \text { Discounting }\end{array}$ & $\begin{array}{l}133 \\
133\end{array}$ & $\begin{array}{l}0.309 \\
0.314\end{array}$ & $\begin{array}{l}0.029 \\
0.029\end{array}$ & $\begin{array}{l}-0.046 \\
-0.037\end{array}$ & $\begin{array}{l}2.321 \\
2.324\end{array}$ \\
\hline Whites & $\begin{array}{l}\text { Profit Under } 0 \% \text { Discounting } \\
\text { Profit Under } 10 \% \text { Discounting }\end{array}$ & $\begin{array}{l}560 \\
560\end{array}$ & $\begin{array}{l}0.260 \\
0.269\end{array}$ & $\begin{array}{l}0.043 \\
0.043\end{array}$ & $\begin{array}{l}-1.791 \\
-1.583\end{array}$ & $\begin{array}{l}23.382 \\
23.438\end{array}$ \\
\hline Nonblacks & $\begin{array}{l}\text { Profit Under } 0 \% \text { Discounting } \\
\text { Profit Under } 10 \% \text { Discounting }\end{array}$ & $\begin{array}{l}571 \\
571\end{array}$ & $\begin{array}{l}0.259 \\
0.268\end{array}$ & $\begin{array}{l}0.042 \\
0.042\end{array}$ & $\begin{array}{l}-1.791 \\
-1.583\end{array}$ & $\begin{array}{l}23.382 \\
23.438\end{array}$ \\
\hline Blacks & $\begin{array}{l}\text { Profit Under } 0 \% \text { Discounting } \\
\text { Profit Under } 10 \% \text { Discounting }\end{array}$ & $\begin{array}{l}122 \\
122\end{array}$ & $\begin{array}{l}0.320 \\
0.325\end{array}$ & $\begin{array}{l}0.032 \\
0.032\end{array}$ & $\begin{array}{l}-0.046 \\
-0.037\end{array}$ & $\begin{array}{l}2.321 \\
2.324\end{array}$ \\
\hline
\end{tabular}

Notes: Profit under $0 \%$ discounting is equal to (unit price - buyer beliefs) ${ }^{*}$ term award.

Profit under $10 \%$ discounting is equal to (unit price - buyer beliefs $/ 1.1$ ) term award.

Data: AHEAD.

Table 4D: Profits Implied by the Mortality Beliefs of the Insured in AHEAD (Beliefs Constructed Using a Constant Hazard Model)

\begin{tabular}{|c|c|c|c|c|c|c|}
\hline Population & Variable: & $\underline{\mathbf{N}}$ & Mean & $\begin{array}{l}\text { Standard } \\
\text { Error }\end{array}$ & Minimum & Maximum \\
\hline Entire & $\begin{array}{l}\text { Prolit Under } 0 \% \text { Discounting } \\
\text { Profit Under } 10 \% \text { Discounting }\end{array}$ & $\begin{array}{l}693 \\
693\end{array}$ & $\begin{array}{l}-0.668 \\
-0.575\end{array}$ & $\begin{array}{l}0.089 \\
0.082\end{array}$ & $\begin{array}{l}-26.494 \\
-23.799\end{array}$ & $\begin{array}{l}16.679 \\
17.344\end{array}$ \\
\hline Males & $\begin{array}{l}\text { Profit Under } 0 \% \text { Discounting } \\
\text { Profit Under } 10 \% \text { Discounting }\end{array}$ & $\begin{array}{l}323 \\
323\end{array}$ & $\begin{array}{l}-0.920 \\
-0.790\end{array}$ & $\begin{array}{l}0.159 \\
0.146\end{array}$ & $\begin{array}{l}-26.494 \\
-23.799\end{array}$ & $\begin{array}{l}16.679 \\
17.344\end{array}$ \\
\hline Females & $\begin{array}{l}\text { Profit Under } 0 \% \text { Discounting } \\
\text { Profit Under } 10 \% \text { Discounting }\end{array}$ & $\begin{array}{l}370 \\
370\end{array}$ & $\begin{array}{l}-0.455 \\
-0.393\end{array}$ & $\begin{array}{l}0.093 \\
0.084\end{array}$ & $\begin{array}{l}-23.003 \\
-20.867\end{array}$ & $\begin{array}{l}1.957 \\
1.975\end{array}$ \\
\hline Nonwhites & $\begin{array}{l}\text { Profit Under } 0 \% \text { Discounting } \\
\text { Profit Under } 10 \% \text { Discounting }\end{array}$ & $\begin{array}{l}133 \\
133\end{array}$ & $\begin{array}{l}-0.199 \\
-0.148\end{array}$ & $\begin{array}{l}0.065 \\
0.060\end{array}$ & $\begin{array}{l}-4.033 \\
-3.630\end{array}$ & $\begin{array}{l}1.900 \\
1.941\end{array}$ \\
\hline Whites & $\begin{array}{l}\text { Profit Under } 0 \% \text { Discounting } \\
\text { Prolit Under } 10 \% \text { Discounting }\end{array}$ & $\begin{array}{l}560 \\
560\end{array}$ & $\begin{array}{l}-0.753 \\
-0.652\end{array}$ & $\begin{array}{l}0.107 \\
0.098\end{array}$ & $\begin{array}{l}-26.494 \\
-23.799\end{array}$ & $\begin{array}{l}16.679 \\
17.344\end{array}$ \\
\hline Nonblacks & $\begin{array}{l}\text { Profit Under } 0 \% \text { Discounting } \\
\text { Prolit Under } 10 \% \text { Discounting }\end{array}$ & $\begin{array}{l}571 \\
571\end{array}$ & $\begin{array}{l}-0.743 \\
-0.643\end{array}$ & $\begin{array}{l}0.105 \\
0.096\end{array}$ & $\begin{array}{l}-26.494 \\
-23.799\end{array}$ & $\begin{array}{l}16.679 \\
17.344\end{array}$ \\
\hline Blacks & $\begin{array}{l}\text { Prolit Under } 0 \% \text { Discounting } \\
\text { Profit Under } 10 \% \text { Discounting }\end{array}$ & $\begin{array}{l}122 \\
122\end{array}$ & $\begin{array}{l}-0.204 \\
-0.151\end{array}$ & $\begin{array}{l}0.071 \\
0.065\end{array}$ & $\begin{array}{l}-4.033 \\
-3.630\end{array}$ & $\begin{array}{l}1.900 \\
1.941\end{array}$ \\
\hline
\end{tabular}

Notes: Profit under $0 \%$ discounting is equal to (unit price - buyer beliets) *term award.

Profit under $10 \%$ discounting is equal to (unit price - buyer beliefs/1.1) *term award.

Data: AHEAD 


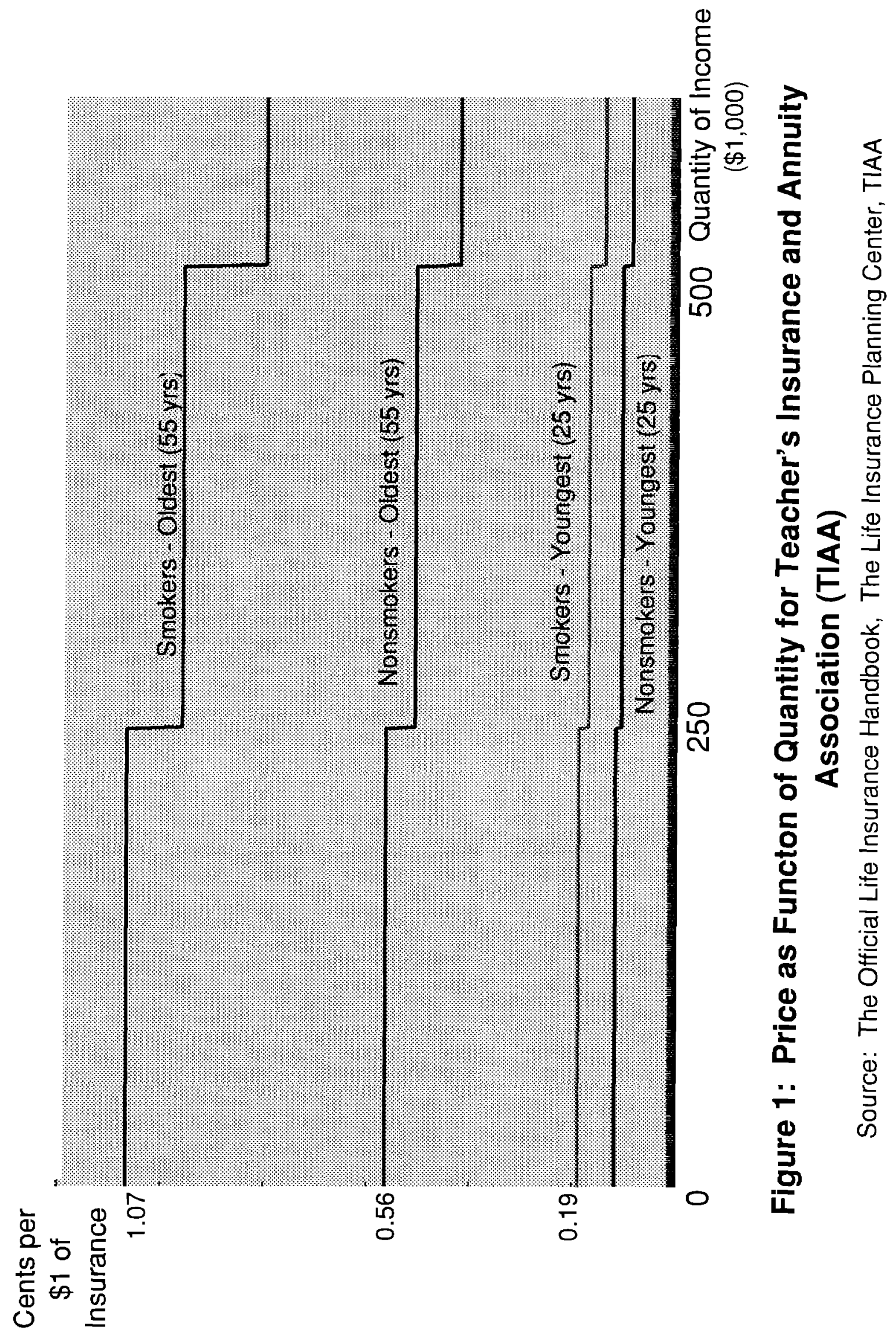




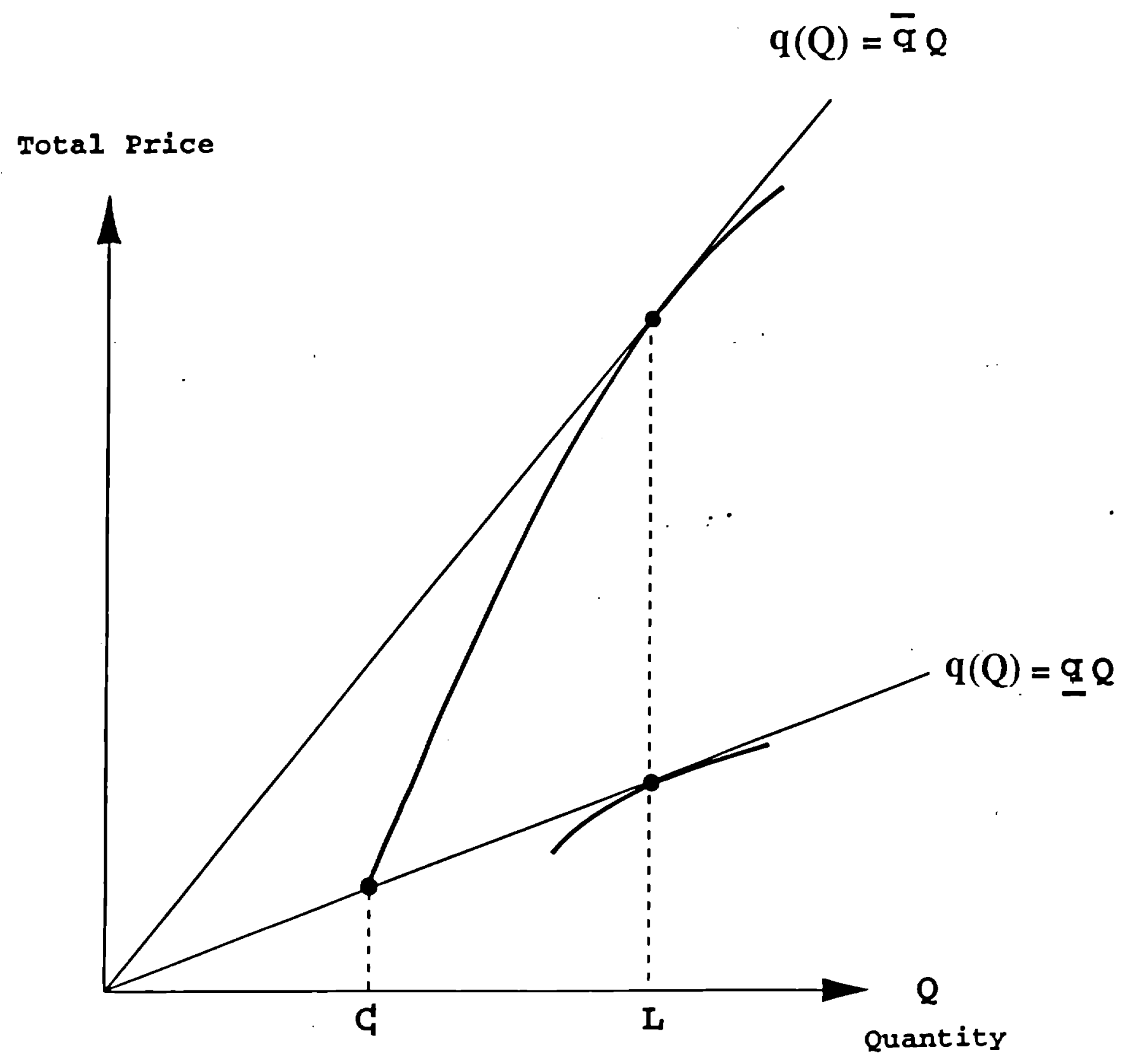

Figure 2: Equilibrium Insurance 


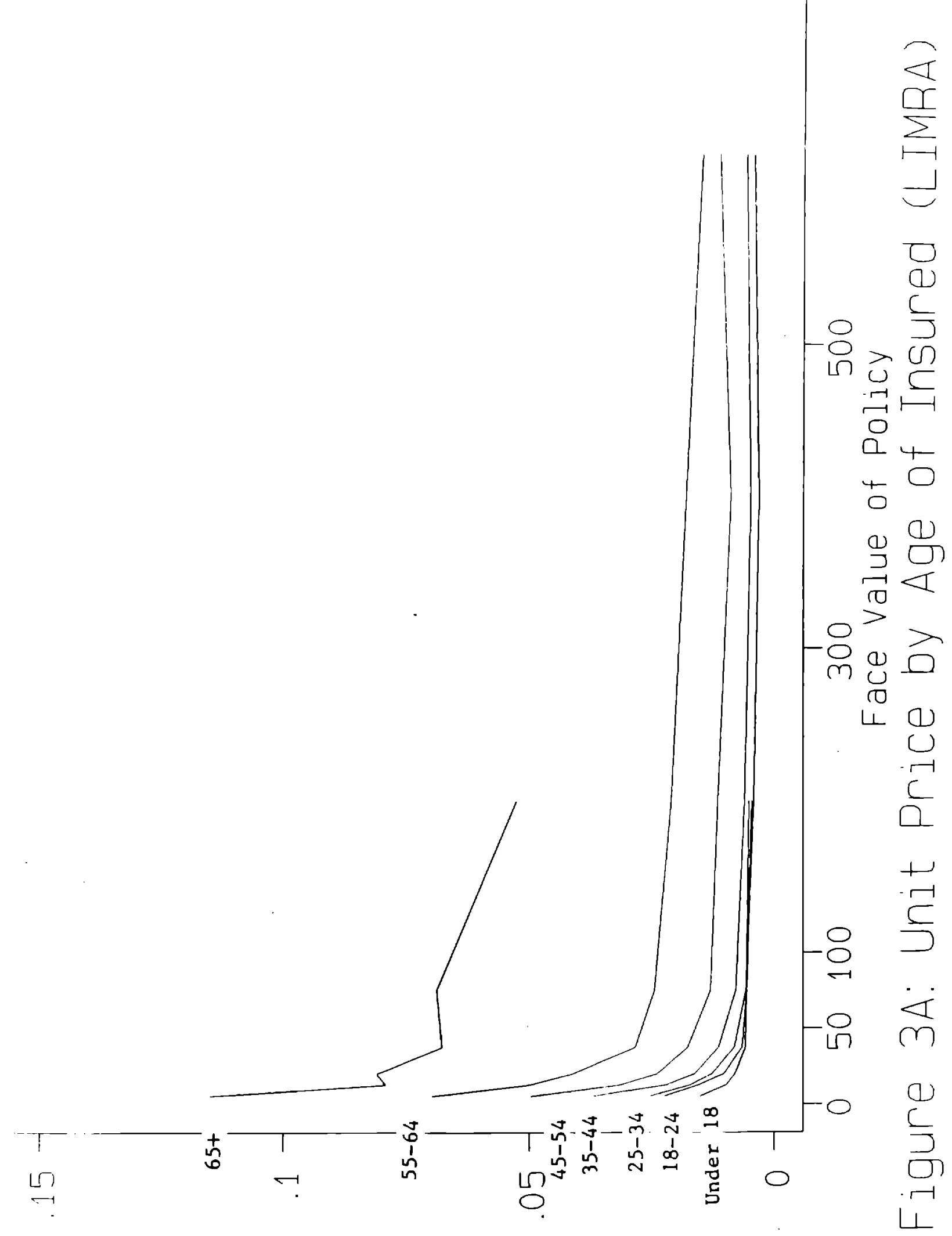

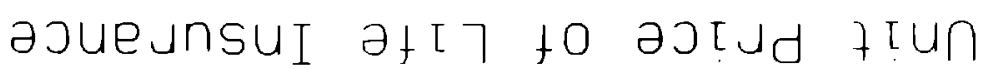




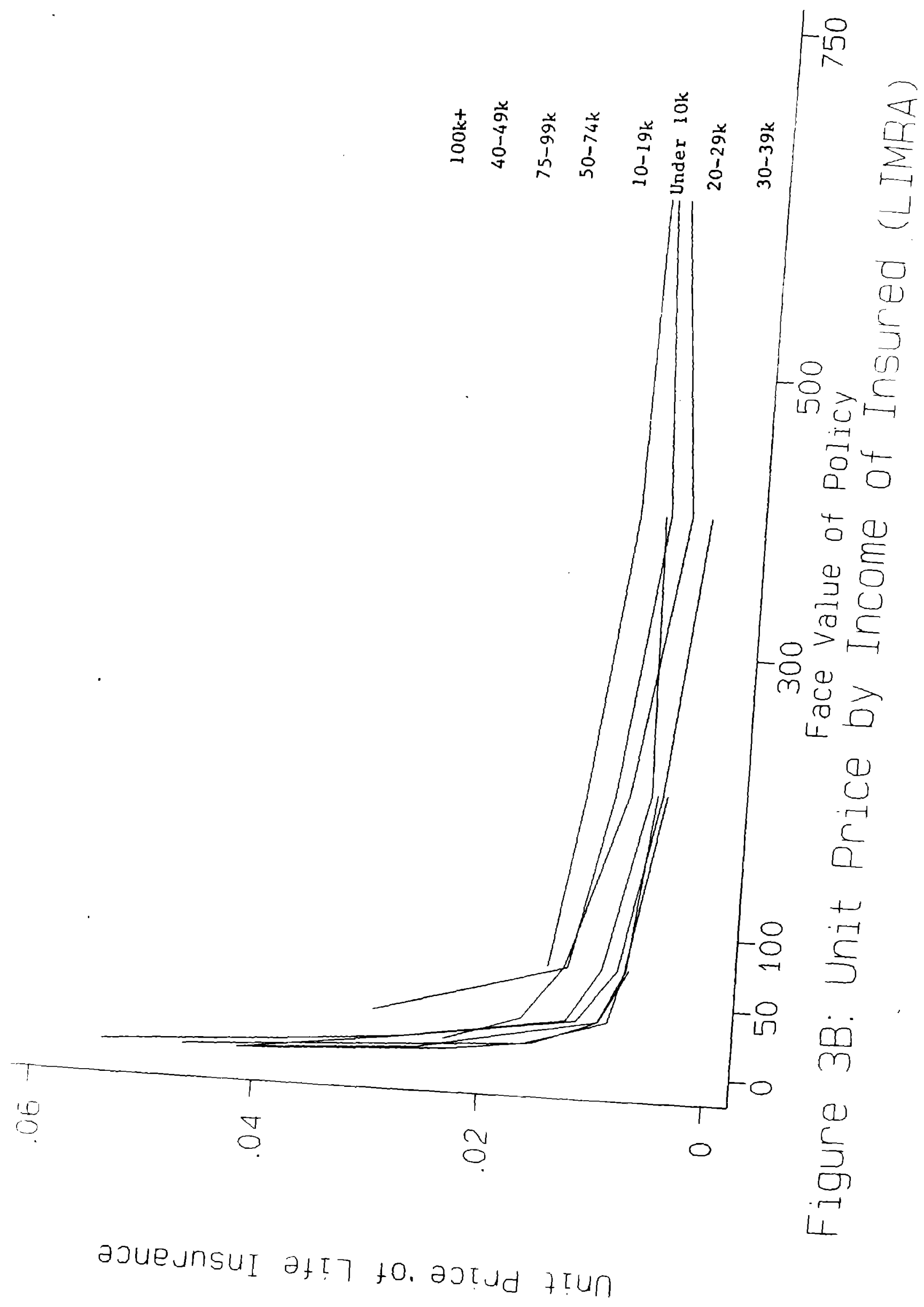




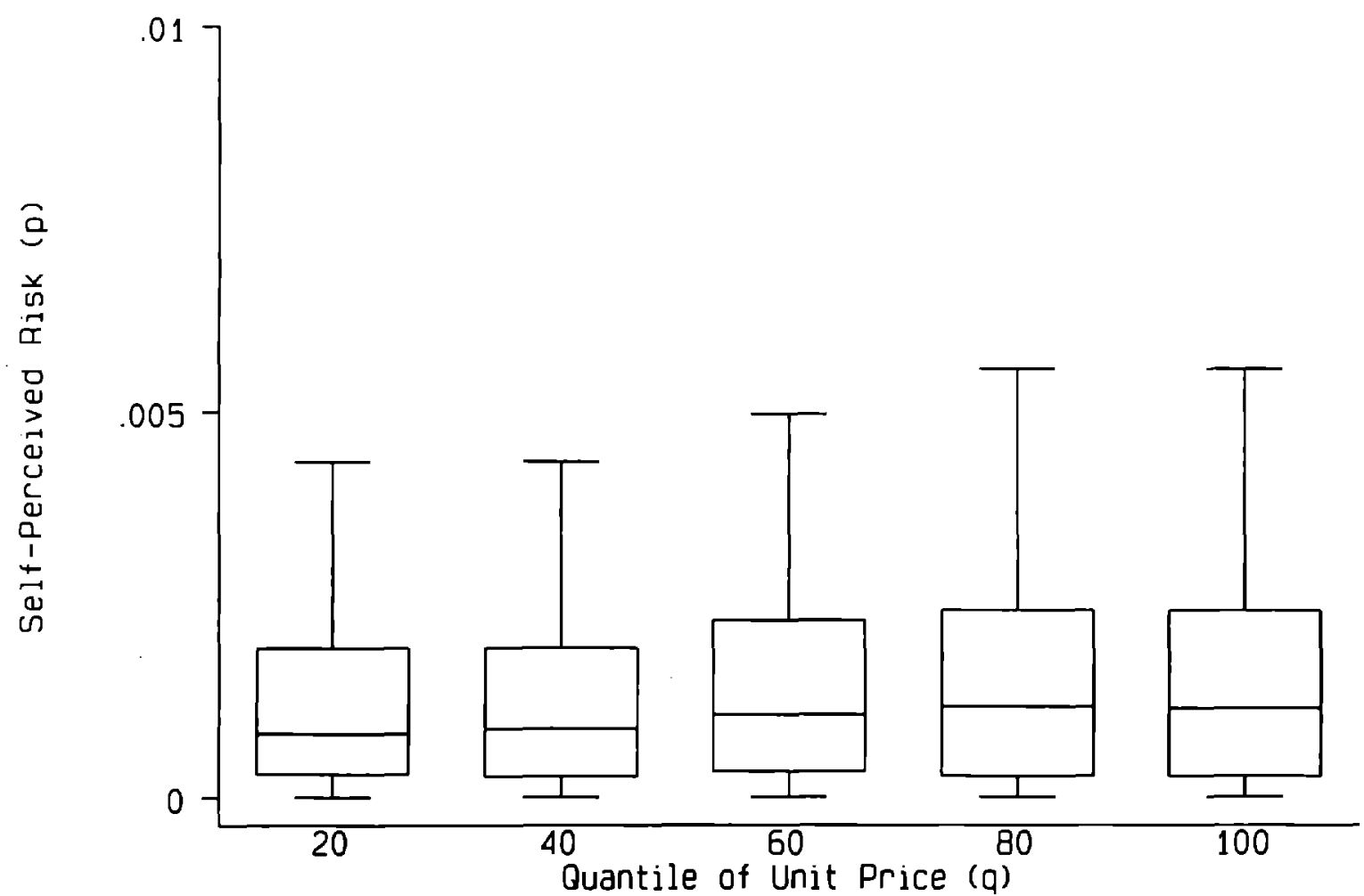

Figure 4A: Unit Prices and Self-Perceived Risk in HRS 


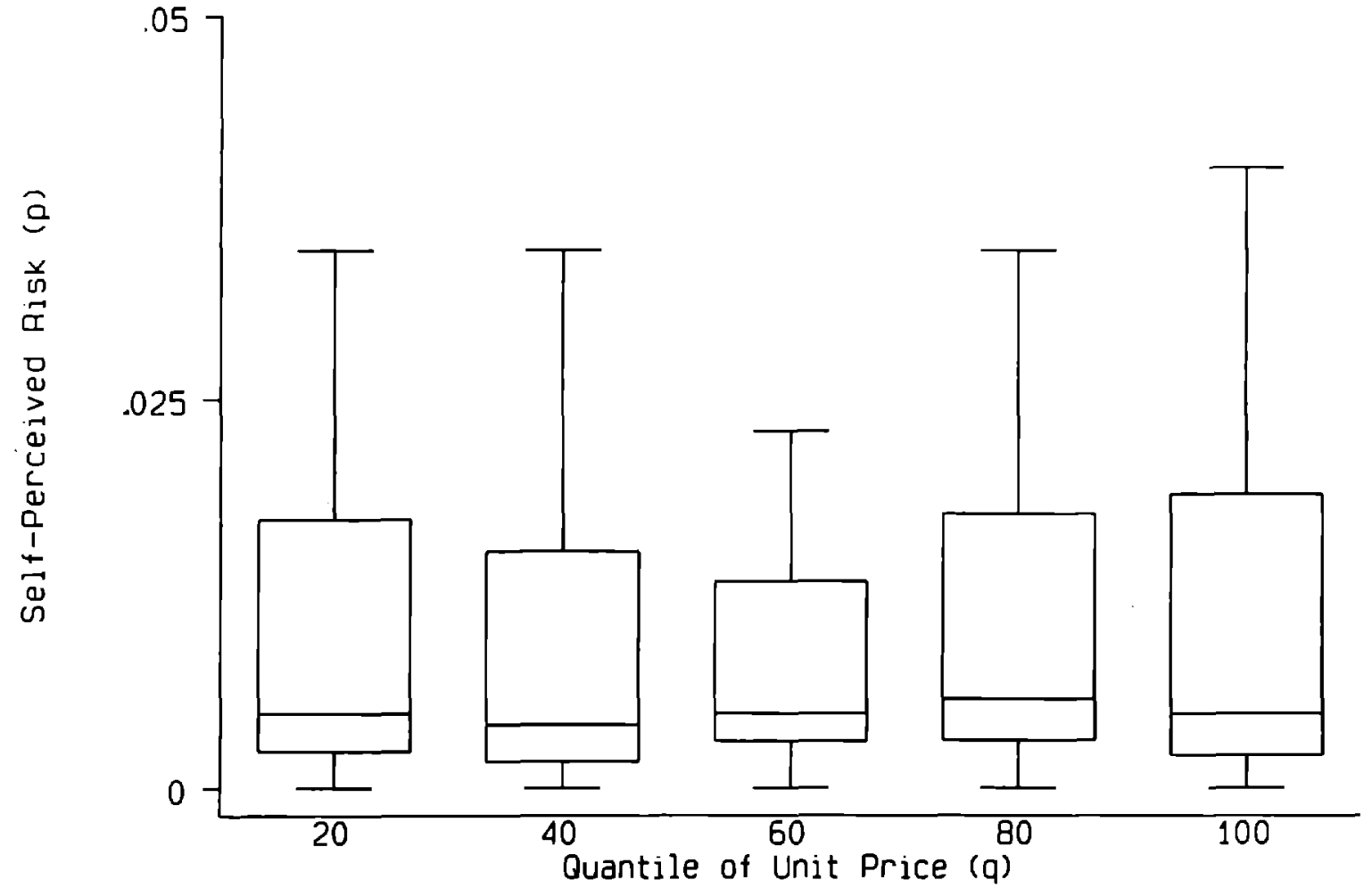

Figure 4B: Unit Prices and Self-Perceived Risk in AHEAD 


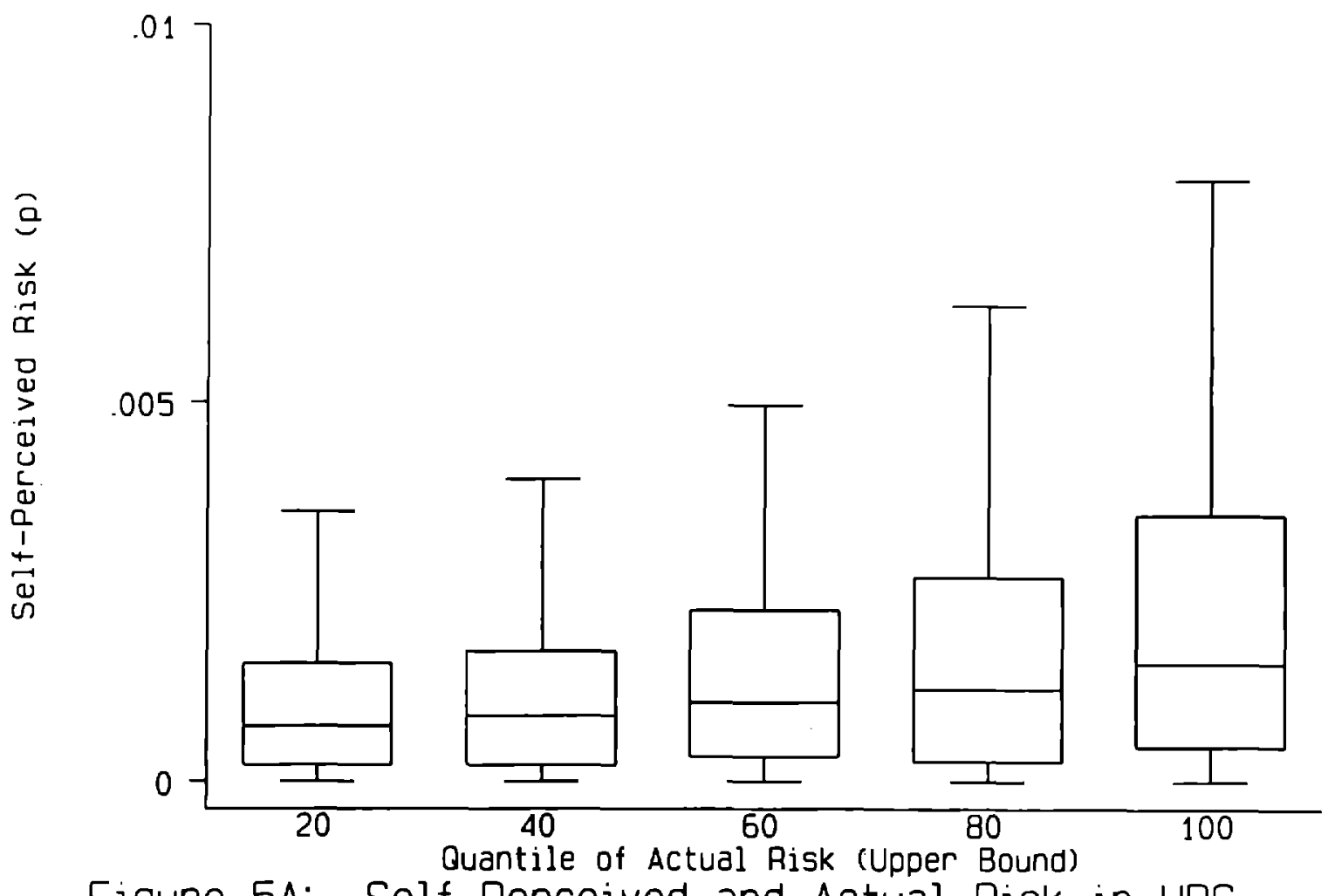

Figure 5A: Self-Perceived and Actual Risk in HRS 


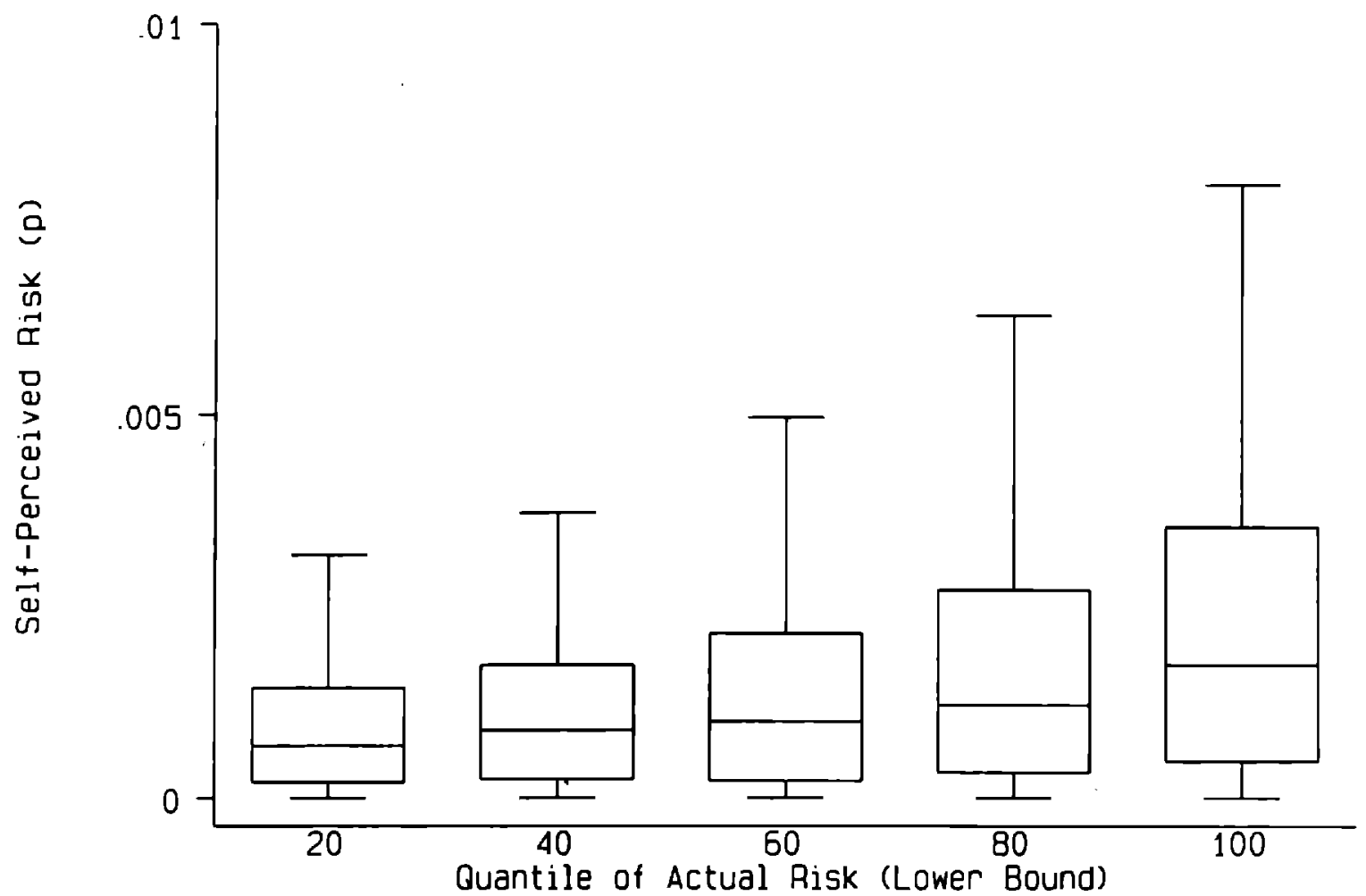

Figure 5B: Self-Perceived and Actual Risk in HRS 

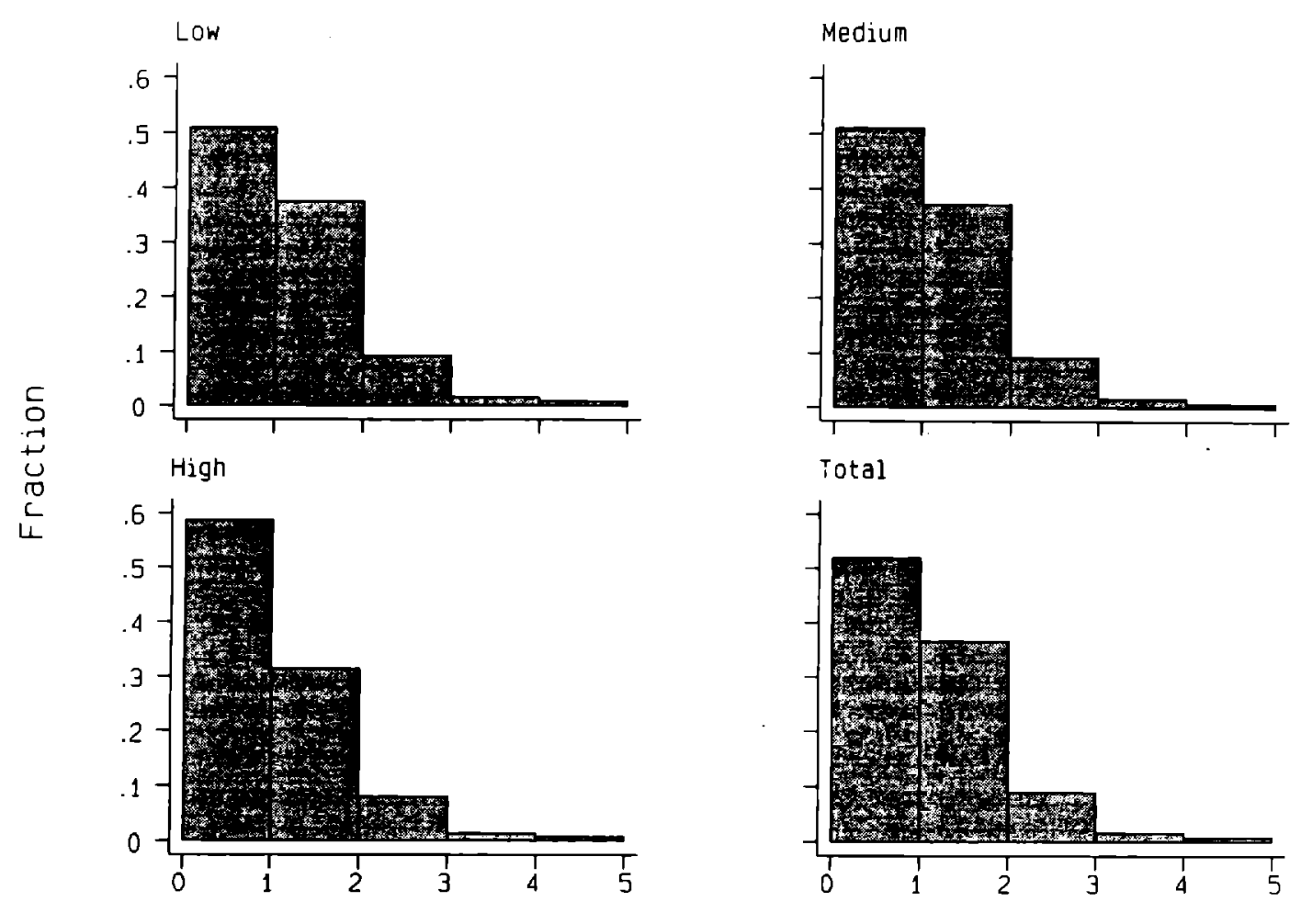

Number of Term Policies Held

Figure 6A: Number of Term Policies Held by Risk in HRS 

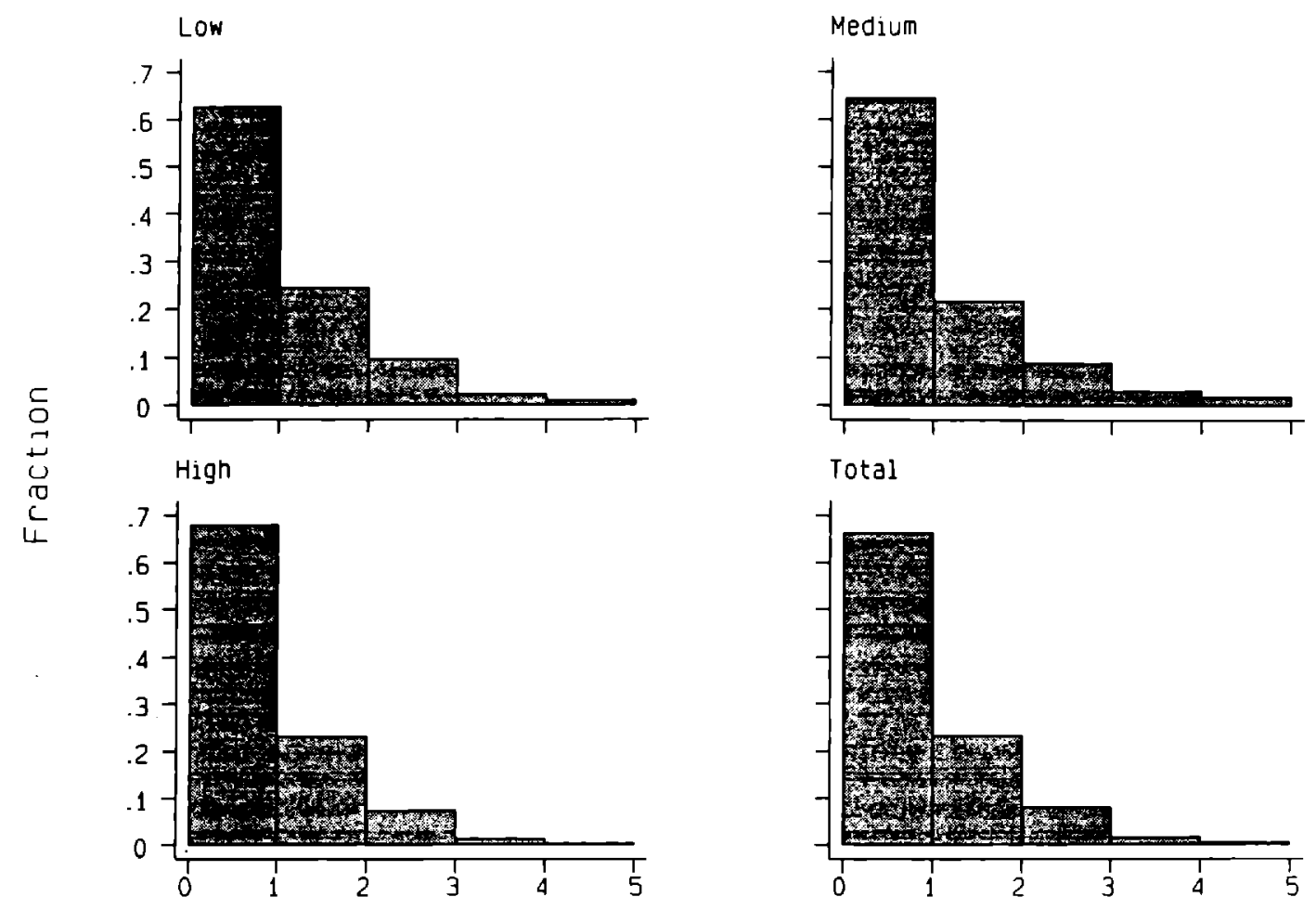

Number of Term Policies Held

Figure 6B: Number of Term Policies Held by Risk in AHEAD 


\begin{tabular}{|c|c|c|c|c|}
\hline Econometrician & Supplier & Demander & Symmetric & Asymmetric \\
\hline \multirow{4}{*}{$Z=1$} & \multirow{2}{*}{$x=1$} & $\mathrm{U}=1$ & $\mathrm{~L}, \mathrm{p} 1$ & $\mathrm{Q}(\mathrm{p} 11), \mathrm{p} 11$ \\
\hline & & $\mathrm{U}=0$ & $\mathrm{~L}, \mathrm{p} 1$ & $\mathrm{Q}(\mathrm{p} 10), \mathrm{p} 10$ \\
\hline & \multirow{2}{*}{$X=0$} & $\mathrm{U}=1$ & $\mathrm{~L}, \mathrm{p} 0$ & $\mathrm{Q}(\mathrm{p} 01), \mathrm{p} 01$ \\
\hline & & $\mathrm{U}=0$ & $\mathrm{~L}, \mathrm{p} 0$ & $\mathrm{Q}(\mathrm{p} 00), \mathrm{p} 00$ \\
\hline \multirow{4}{*}{$\mathrm{Z}=0$} & \multirow{2}{*}{$x=1$} & $\mathrm{U}=1$ & $\mathrm{~L}, \mathrm{pl}$ & $\mathrm{Q}(\mathrm{p} 11), \mathrm{p} 11$ \\
\hline & & $\mathrm{U}=0$ & $\mathrm{~L}, \mathrm{pl}$ & $\mathrm{Q}(\mathrm{p} 10), \mathrm{p} 10$ \\
\hline & \multirow{2}{*}{$X=0$} & $\mathrm{U}=1$ & $\mathrm{~L}, \mathrm{p} 0$ & $\mathrm{Q}(\mathrm{p} 01), \mathrm{p} 01$ \\
\hline & & $\mathrm{U}=0$ & $\mathrm{~L}, \mathrm{p} 0$ & $\mathrm{Q}(\mathrm{p} 00), \mathrm{p} 00$ \\
\hline
\end{tabular}

